\title{
Leonurus sibiricus L. ethanol extract promotes osteoblast differentiation and inhibits osteoclast formation
}

\author{
JAE-HYUN KIM*, MINSUN KIM* , HYUK-SANG JUNG and YOUNGJOO SOHN \\ Department of Anatomy, College of Korean Medicine, Kyung Hee University, Seoul 02447, Republic of Korea
}

Received February 19, 2019; Accepted July 5, 2019

DOI: $10.3892 /$ ijmm.2019.4269

\begin{abstract}
Leonurus sibiricus L. (LS) is a medicinal plant used in East Asia, Europe and the USA. LS is primarily used in the treatment of gynecological diseases, and recent studies have demonstrated that it exerts anti-inflammatory and antioxidant effects. To the best of our knowledge, the present study demonstrated for the first time that LS may promote osteoblast differentiation and suppress osteoclast differentiation in vitro, and that it inhibited lipopolysaccharide (LPS)-induced bone loss in a mouse model. LS was observed to promote the osteoblast differentiation of MC3T3-E1 cells and upregulate the expression of runt-related transcription factor 2 (RUNX2), a key gene involved in osteoblast differentiation. This resulted in the induction of the expression of various osteogenic genes, including alkaline phosphatase (ALP), osteonectin (OSN), osteopontin (OPN), type I collagen (COL1) and bone sialoprotein (BSP). LS was also observed to inhibit osteoclast differentiation and bone resorption. The expression levels of nuclear factor of activated T-cells 1 (NFATc1) and c-Fos were inhibited following LS treatment. NFATc1 and c-Fos are key markers of osteoclast differentiation that inhibit receptor activator of nuclear factor- $\kappa \mathrm{B}$ ligand (RANKL)-induced mitogen-activated protein kinase (MAPKs) and nuclear factor $(\mathrm{NF})-\kappa \mathrm{B}$. As a result, LS suppressed the expression of osteoclast-associated genes, such as matrix metallopeptidase-9 (MMP-9), cathepsin K (Ctsk), tartrate-resistant acid phosphatase (TRAP), osteoclast-associated immunoglobulin-like receptor (OSCAR), c-src, c-myc, osteoclast stimulatory transmembrane protein (OC-STAMP) and ATPase $\mathrm{H}+$ transporting V0 subunit d2 (ATP6v0d2). Consistent with the in vitro results, LS inhibited the reduction in bone mineral
\end{abstract}

Correspondence to: Professor Youngjoo Sohn, Department of Anatomy, College of Korean Medicine, Kyung Hee University, 26-6 Kyungheedae-ro, Dongdaemun-gu, Seoul 02447, Republic of Korea

E-mail: youngjoos@khu.ac.kr

*Contributed equally

Key words: Leonurus sibiricus L., motherwort, bone metabolic disease, osteoblast, osteoclast, lipopolysaccharide-induced osteoporosis density and the bone volume/total volume ratio in a mouse model of LPS-induced osteoporosis. These results suggest that LS may be a valuable agent for the treatment of osteoporosis and additional bone metabolic diseases.

\section{Introduction}

Bone quality is maintained by the balance between osteoclastic bone resorption and osteoblastic bone formation. The disruption of this balance leads to bone metabolic diseases, such as osteoporosis, arthritis, periodontitis and Paget's disease (1). Osteoporosis is a metabolic bone disease characterized by low bone mass, whereby the microstructure of the bone tissue is destroyed, increasing the probability of fractures. In recent years, an increase in the elderly population has led to a high incidence of osteoporosis, which is a serious health concern (2). In order to treat osteoporosis, bone resorption inhibitors, such as bisphosphonates and denosumab have been developed (3). However, patients treated with these inhibitors experience severe side-effects, including uterine cancer, breast cancer and osteonecrosis $(4,5)$. In addition, as patients with osteoporosis usually present with significant bone loss, promoting osteoblast activity is vital. For this reason, it is necessary to identify natural products that inhibit osteoclast differentiation and promote osteoblast differentiation.

Osteoblasts are derived from mesenchymal stem cells and are located in regions of bone regeneration. Bone morphogenetic protein 2 (BMP-2) and runt-related transcription factor 2 (RUNX2) signaling pathways are known to be important in mediating osteoblast differentiation and activation (6). Activated RUNX2 regulates the expression of osteogenic genes, including alkaline phosphatase (ALP), osteonectin (OSN), osteopontin (OPN), type I collagen (COL1) and bone sialoprotein (BSP), which leads to the successful differentiation of osteoblasts (7). Receptor activator of nuclear factor $\kappa-B$ ligand (RANKL) is a tumor necrosis factor (TNF)-associated, activation-induced cytokine expressed in osteoblasts that is essential for osteoclastogenesis (8). RANKL binds to RANK on the surface of osteoclast precursor cells, and RANK then stimulates mitogen-activated protein kinases (MAPKs), nuclear factor (NF) $\kappa \mathrm{B}$ and $\mathrm{c}-\mathrm{Fos}$ to induce nuclear factor of activated T cells 1 (NFATc1) (9). NFATc1 is essential for osteoclast differentiation and regulates the expression of various osteoclast-associated genes, such as tartrate-resistant acid 
phosphatase (TRAP), matrix metallopeptidase-9 (MMP-9), cathepsin K (Ctsk), osteoclast-associated immunoglobulin-like receptor (OSCAR), c-src, c-myc, osteoclast stimulatory transmembrane (OC-STAMP) and ATPase H+ transporting V0 subunit d2 (ATP6v0d2) (10).

Leonurus sibiricus L. (LS), also known as motherwort, is currently used as a medicinal plant in various regions, such as East Asia, Europe and the USA. LS is traditionally used in the treatment of a variety of female-related conditions, including menstrual pain, dysmenorrhea and amenorrhea. For this reason, it is known as 'IG-MO-CHO' in Korean, which translates into 'herb that is beneficial to mother' (11). In addition, LS is used for the treatment of renal diseases, such as acute nephritis and kidney stones (12). In oriental medicine, the kidney is considered to be the key organ of bone control (13). Therefore, kidney-enhancing medications, such as LS, have been used for the treatment of weakened bones. Previous studies have demonstrated that LS exerts numerous biological activities, such as anti-inflammatory, antioxidant (14), anti-bacterial (15) and angiogenic effects (16). Among these, the anti-inflammatory and antioxidant effects have been demonstrated to be associated with the treatment of bone metabolic disease (17). Therefore, the authors of the present study hypothesized that LS may exert a positive effect on bone metabolism. However, to the best of our knowledge, no studies published to date have investigated the effects of LS on osteoblast differentiation and osteoclastogenesis.

In the present study, the effects of LS on osteoblast differentiation and osteoclast differentiation, which play a major role in bone metabolism, were investigated. The effects of LS in an in vivo model of lipopolysaccharide (LPS)-induced osteoporosis were also examined.

\section{Materials and methods}

Reagents. Minimum essential Eagle's medium, $\alpha$-modification $(\alpha$-MEM), fetal bovine serum (FBS) and penicillin/streptomycin (P/S) were supplied by Gibco; Thermo Fisher Scientific, Inc. Dulbecco's modified Eagle's medium (DMEM) was procured from Welgene, Inc. Alizarin Red S was obtained from Duksan Co., Ltd. RANKL was purchased from Peprotech, Inc. Rutin, dimethylsulfoxide (DMSO) and the TRAP assay kit were purchased from Sigma-Aldrich; Merck KGaA. Osteo strip well plates were purchased from Corning Inc. Anti-RUNX2, anti-BMP-2, anti-Ctsk and anti-MMP-9 antibodies were purchased from Abcam. Anti-phosphorylated (p)-extracellular signal-regulated kinase 1/2 (ERK1/2), anti-ERK1/2, anti-p-c-Jun N-terminal kinase (JNK), anti-JNK, anti-p-p38, anti-p38, anti-NF- $\kappa$ B and anti-p-NF- $\mathrm{KB}$ antibodies were supplied by Cell Signaling Technology, Inc. Anti-NFATc1 was procured from BD Biosciences, and anti-c-Fos, anti-actin and anti-lamin B antibodies were purchased from Santa Cruz Biotechnology, Inc. Secondary antibodies were procured from Jackson ImmunoResearch Laboratories, Inc. The reverse transcriptase kit and SYBR-Green solution was supplied by Invitrogen; Thermo Fisher Scientific, Inc. Taq polymerase was purchased from Kapa Biosystems; Roche Diagnostics. PCR primers were purchased from Genotech Corp. All of the chemicals used in the experiments were analytical grade for cell culture.
Preparation of LS. LS was purchased from Omniherb and was certified by Professor Yungmin Bu at the Herbology Laboratory, College of Korean Medicine. Voucher specimens of the plants used in the current study were stored at the Department of Anatomy Herbarium (ref. no. KHU-ANA-Et010). LS was soaked in $80 \%$ ethanol for 1 week before the extract was filtered through filter paper, and then concentrated under reduced pressure and lyophilized to obtain a powder (yield, 7.83\%). The extracts were stored at $-20^{\circ} \mathrm{C}$ until required. Prior to use in the in vitro experiments, LS was filtered through a sterile filter (pore size, $0.22 \mu \mathrm{m}$ ), diluted in DMSO and not treated with $>0.1 \%$ of the total volume of cell culture medium.

High-performance liquid chromatography (HPLC) analysis. To quantitatively evaluate the LS extract, HPLC was performed using rutin; a reference compound of LS. Rutin (standard stock solution, $1,000 \mu \mathrm{g} / \mathrm{ml}$ ) were prepared in methanol. LS and rutin were analyzed using an A Waters 2695 system equipped with a Waters 2487 Dual $\lambda$ absorbance detector. Separation was achieved using a C18 guard column with Xbridge-C18 (250x6 mm, $5 \mu \mathrm{m})$. All solvents were filtered through a $45-\mu \mathrm{m}$ filter and the elution time was 0-30 min. The binary mobile phase was acetonitrile (A) and water (B) at a composition of $10 \% \mathrm{~A}$ from 0 to $10 \mathrm{~min}$ and $50 \% \mathrm{~A}$ from 10 to $30 \mathrm{~min}$. The flow rate was $1.0 \mathrm{ml} / \mathrm{min}$ and rutin was detected at $254 \mathrm{~nm}$.

Cell culture and assessment of cell viability. C57BL/6 mouse calvaria MC3T3-E1 cells were purchased from the American Type Culture Collection (ATCC), and the RAW 264.7 murine macrophage cell line was purchased from the Korean Cell Line Bank. The MC3T3-E1 cells were cultured in $\alpha$-MEM (without ascorbic acid) supplemented with $10 \%$ FBS and $1 \% \mathrm{P} / \mathrm{S}$, and RAW 264.7 cells were cultured in DMEM supplemented with $10 \% \mathrm{FBS}$ and $1 \% \mathrm{P} / \mathrm{S}$. Cell lines were maintained in a cell incubator at $37^{\circ} \mathrm{C}$ and $5 \% \mathrm{CO}_{2}$. To analyze cytotoxicity levels, MC3T3-E1 cells $\left(1 \times 10^{4}\right.$ cells/well) treated with or without LS for 3,7 and 14 days, or RAW 264.7 cells $\left(5 \times 10^{3}\right.$ cells/well) treated with or without LS and RANKL for 1 and 5 days, were seeded in 96-well-plates and then treated with MTS solution for $2 \mathrm{~h}$. The absorbance was subsequently measured using an enzyme-linked immunosorbent assay (ELISA) reader (Versamax; Molecular Devices, LLC) at a wavelength of $490 \mathrm{~nm}$.

Von Kossa and Alizarin Red S staining. The MC3T3-E1 cells were seeded in 6-well-plates at $5 \times 10^{4}$ cells/well and incubated in differentiation medium consisting of $\alpha$-MEM, $25 \mu \mathrm{g} / \mathrm{ml}$ ascorbic acid and $10 \mathrm{mM} \beta$-glycerophosphate with or without LS for 21 days. The culture medium was refreshed every 2 days. For Von Kossa staining, the nodules were first fixed in $80 \% \mathrm{Et}-\mathrm{OH}$ and washed 3 times with deionized water The fixed nodules were incubated at room temperature with $1 \%$ sliver nitrate for $40 \mathrm{~min}$ under ultraviolet light prior to incubation with 5\% sodium thiosulfate for $10 \mathrm{~min}$. The dried plate was imaged using a camera. For Alizarin Red S staining, formed mineralized nodules were fixed with $80 \% \mathrm{Et}-\mathrm{OH}$ and then stained with Alizarin Red S solution at room temperature for $3 \mathrm{~min}$. The stained nodules were washed 3 times with Dulbecco's phosphate-buffered saline (Gibco; Thermo Fisher Scientific, Inc.). The formed nodules were subsequently photographed with a camera before the dye was extracted by 
the addition of $10 \mathrm{mM}$ sodium phosphate $(\mathrm{pH}$ 7.0) diluted in $10 \%$ cetylpyridinium chloride for $15 \mathrm{~min}$. The extracted dyes were measured measured using an ELISA reader at an absorbance of $570 \mathrm{~nm}$.

Western blot analysis. The cells were lysed using radioimmunoprecipitation assay buffer $(50 \mathrm{mM}$ Tris-Cl, $150 \mathrm{mM}$ $\mathrm{NaCl}, 1 \% \mathrm{NP}-40,0.5 \%$ sodium deoxycholate and $0.1 \%$ SDS) with protease inhibitor and phosphatase inhibitor 2 and 3 cocktails (Sigma Aldrich; Merck KGaA). Protein concentrations were determined using a bicinchoninic acid assay kit using bovine serum albumin as the standard. An equivalent quantity of protein for each sample (10-30 $\mu \mathrm{g})$ was separated by $10 \%$ SDS-PAGE and transferred to nitrocellulose membranes via electrophoresis. The membranes were blocked with $5 \%$ skim milk and incubated with specific primary antibodies against RUNX2 (cat. no. ab76956; dilution, 1:1,000), BMP-2 (cat. no. ab14933; dilution, 1:1,000), $\beta$-actin (cat. no. sc-8432; dilution, 1:500), p-ERK (cat. no. 4370S; dilution, 1:1,000), ERK (cat. no. 4695S; dilution, 1:1,000), p-JNK (cat. no. 4668S; dilution, 1:1,000), JNK (cat. no. 9258S; dilution, 1:1,000), p-p38 (cat. no. 4511S; dilution, 1:500), p38 (cat. no. 9212L; dilution, 1:1,000), $\mathrm{NF}-\kappa \mathrm{B}$ (cat. no. 8242S; dilution, 1:1,000), p-NF-кB (cat. no. 3033S; dilution, 1:500), lamin B (cat. no. sc6216; dilution, 1:1,000), NFATc1 (cat. no. 556602; dilution, 1:1,000), c-Fos (cat. no. sc-447; dilution, 1:200), MMP-9 (cat. no. ab38898; dilution, 1:1,000) and Ctsk (cat. no. ab19027; dilution, $1: 1,000)$ at $4^{\circ} \mathrm{C}$ overnight. The membranes were then incubated with secondary antibodies (cat. no. 111-035-045, 115-035-062; dilution, 1:10,000) at room temperature for $1 \mathrm{~h}$ and chemiluminescence was measured using enhanced chemiluminescence substrate (Santa Cruz Biotechnology, Inc.). Band densities were quantified using ImageJ software version 1.51j8 (National Institutes of Health).

Reverse transcription-semi-quantitative polymerase chain reaction $(P C R)$. Total RNA was extracted using TRIzol reagent (Takara Bio, Inc.) according to the manufacturer's protocol. A total of $2 \mu \mathrm{g}$ total RNA was reverse transcribed into cDNA using a reverse transcriptase enzyme (Invitrogen; Thermo Fisher Scientific, Inc.). RT-PCR was performed using the C1000 Touch ${ }^{\mathrm{TM}}$ Thermal Cycler (Bio-Rad, Laboratories, Inc.) and Taq polymerase (Kapa Biosystems; Roche Diagnostics). The thermal cycling parameters were as follows: $30 \mathrm{sec}$ at $94^{\circ} \mathrm{C}$ (denaturation), $30 \mathrm{sec}$ at $53-58^{\circ} \mathrm{C}$ (annealing) and $30 \mathrm{sec}$ at $72^{\circ} \mathrm{C}$ (extension). The temperature and number of cycles for each gene are listed in Table I. The final PCR mixtures were electrophoresed on agarose gels stained with SYBR-Green (Invitrogen; Thermo Fisher Scientific, Inc.) and bands were quantified using ImageJ software version $1.51 \mathrm{j} 8$.

TRAP and pit formation assay. To generate osteoclasts from RAW 264.7 cell cultures, the RAW 264.7 cells were first seeded at a density of $5 \times 10^{3}$ cells/well in 96-well-plates containing differentiation medium ( $\alpha$-MEM containing $100 \mathrm{ng} / \mathrm{ml}$ RANKL with or without LS) and incubated in a cell incubator at $37^{\circ} \mathrm{C}$ for 5 days. The culture medium was refreshed on days 2 and 4 . The differentiated cells were fixed with $10 \%$ formalin for $10 \mathrm{~min}$ and stained using the TRAP kit according to the manufacturer's protocol. The cells were then transferred to a new plate and an equal volume of TRAP solution [4.93 mg p-nitrophenyl phosphate (PNPP) in $0.5 \mathrm{M}$ $750 \mathrm{ml}$ acetate solution, mixed with $150 \mathrm{ml}$ tartrate acid solution] was added followed by incubation at $37^{\circ} \mathrm{C}$ for $30 \mathrm{~min}$. The reaction was then inhibited by the addition of $0.5 \mathrm{M} \mathrm{NaOH}$, and the absorbance was measured using an ELISA reader at a wavelength of $405 \mathrm{~nm}$. To evaluate bone resorption activity, RAW 264.7 cells $\left(5 \times 10^{3}\right.$ cells/well) were cultured in osteo strip well plates containing differentiation medium $(\alpha$-MEM containing $100 \mathrm{ng} / \mathrm{ml}$ RANKL with or without LS) and incubated for 5 days. The cell culture medium was refreshed on days 2 and 4. Following differentiation, the medium was removed and the cells were dissolved with $\mathrm{NaClO}$ before the plate was allowed to dry. The number of TRAP-positive cells and the area of the pit formation were measured using ImageJ software.

F-actin ring immunofluorescence assay. To evaluate F-actin ring formation, the RAW 264.7 cells $\left(5 \times 10^{3}\right.$ cells/well) were cultured in 96-well plates containing differentiation medium $(\alpha-M E M$ containing $100 \mathrm{ng} / \mathrm{ml}$ RANKL with or without LS) and incubated in a cell incubator at $37^{\circ} \mathrm{C}$ for 5 days. The differentiated cells were fixed with $4 \%$ paraformaldehyde for $20 \mathrm{~min}$ and permeabilized with $0.1 \%$ Triton X-100 in PBS for 5 min. The cells were then stained using the Acti-stain ${ }^{\mathrm{TM}} 488$ Fluorescent Phalloidin (Cytoskeleton Inc.) at room temperature in the dark for $30 \mathrm{~min}$. The cells were washed with PBS, and the nuclei were then counterstained with 4',6-diamidino-2-phenylindole (DAPI, Sigma Aldrich; Merck KGaA). The formation of the actin ring was captured using an immunofluorescence microscope (Cellena; Logosbio).

Animal experiments. Institute of Cancer Research (ICR) CD-1 mice (male; age, 4 weeks; weighing, 27-29 g) were purchased from Nara Biotech, Co., Ltd. Animal experiments proceeded with permission from the Kyunghee University Animal Committee [ref. no. KHUASP(SE)-15-095]. The mice were maintained under $12 \mathrm{~h}$ light/dark cycle at $22-24^{\circ} \mathrm{C}$ at a relative humidity of $55-55 \%$ with free access to food and water. The mice were allowed to acclimatize to the laboratory conditions at the animal breeding facility for 1 week. The animal model of osteoporosis was established by an intraperitoneal injection of LPS, as previously described $(18,19)$. The mice were divided into the following 3 groups (n=6/group): Group 1, mice treated with $100 \mu 1$ PBS via intraperitoneal injection and orally administered with distilled water daily; group 2, mice treated with LPS ( $5 \mathrm{mg} / \mathrm{kg}$ body weight) via intraperitoneal injection and orally administered with distilled water daily; and group 3, mice treated with LPS via intraperitoneal injection and orally administered with LS at a concentration of $100 \mathrm{mg} / \mathrm{kg}$ daily. PBS or LPS administration were carried out on days 1 and 4 . The humane endpoint of this experiment was as follows: Dirty hair and eye discharge, self-injury and anxiety, vomiting and hemoptysis, inactivity, anxiety and headache). No abnormal signs that signified the humane endpoints of the experiment were observed from any of the mice during the experiment. All mice were sacrificed 
Table I. Primer sequences used for reverse transcription semi-quantitative PCR.

\begin{tabular}{|c|c|c|c|c|c|}
\hline Gene name & Sequence & Accession no. & Base pair & $\begin{array}{l}\text { Annealing } \\
\text { temperature }\end{array}$ & Cycle \\
\hline Runx2 & $\begin{array}{l}\text { F: CGGCCCTCCCTGAACTCT } \\
\text { R: TGCCTGCCTGGGATCTGTA }\end{array}$ & NM_001145920.2 & 75 & $60^{\circ} \mathrm{C}$ & 38 \\
\hline $\begin{array}{l}\text { Alpl } \\
(A L P)\end{array}$ & $\begin{array}{l}\text { F: CGGGACTGGTACTCGGATAA } \\
\text { R: TGAGATCCAGGCCATCTAGC }\end{array}$ & NM_001287172.1 & 208 & $55^{\circ} \mathrm{C}$ & 42 \\
\hline $\begin{array}{l}\text { Sparc } \\
(O S N)\end{array}$ & $\begin{array}{l}\text { F: AAACATGGCAAGGTGTGTGA } \\
\text { R: TGCATGGTCCGATGTAGTC }\end{array}$ & NM_001290817.1 & 217 & $54^{\circ} \mathrm{C}$ & 35 \\
\hline $\begin{array}{l}\text { Sppl } \\
(O P N)\end{array}$ & $\begin{array}{l}\text { F: TCTGATGAGACCGTCACTGC } \\
\text { R: AGGTCCTCATCTGTGGCATC }\end{array}$ & NM_001290377.1 & 170 & $53^{\circ} \mathrm{C}$ & 38 \\
\hline $\begin{array}{l}\text { Collal } \\
(\text { COLl) }\end{array}$ & $\begin{array}{l}\text { F: GCTCCTCTTAGGGGCCACT } \\
\text { R: CCACGTCTCACCATTGGGG }\end{array}$ & NM_007742.4 & 103 & $60^{\circ} \mathrm{C}$ & 38 \\
\hline $\begin{array}{l}I b s p \\
(B S P)\end{array}$ & $\begin{array}{l}\text { F: AAAGTGAAGGAAAGCGACGA } \\
\text { R: GTTCCTTCTGCACCTGCTTC }\end{array}$ & NM_008318.3 & 215 & $53^{\circ} \mathrm{C}$ & 40 \\
\hline Nfatcl & $\begin{array}{l}\text { F: TGCTCCTCCTCCTGCTGCTC } \\
\text { R: CGTCTTCCACCTCCACGTCG }\end{array}$ & NM_198429.2 & 480 & $58^{\circ} \mathrm{C}$ & 32 \\
\hline $\begin{array}{l}\text { Fos } \\
(c-F o s)\end{array}$ & $\begin{array}{l}\text { F: ATGGGCTCTCCTGTCAACAC } \\
\text { R: GGCTGCCAAAATAAACTCCA }\end{array}$ & NM_010234.3 & 480 & $58^{\circ} \mathrm{C}$ & 33 \\
\hline Мтр-9 & $\begin{array}{l}\text { F: CGACTTTTGTGGTCTTCCCC } \\
\text { R: TGAAGGTTTGGAATCGACCC }\end{array}$ & NM_013599.4 & 258 & $58^{\circ} \mathrm{C}$ & 30 \\
\hline Ctsk & $\begin{array}{l}\text { F: AGGCGGCTATATGACCACTG } \\
\text { R: CCGAGCCAAGAGAGCATATC }\end{array}$ & NM_007802.4 & 403 & $58^{\circ} \mathrm{C}$ & 26 \\
\hline $\begin{array}{l}\text { Tnfrsflla } \\
(\text { RANK) }\end{array}$ & $\begin{array}{l}\text { F: AAACCTTGGACCAACTGCAC } \\
\text { R: ACCATCTTCTCCTCCCHAGT }\end{array}$ & NM_009399.3 & 377 & $53^{\circ} \mathrm{C}$ & 35 \\
\hline Acp5 (TRAP) & $\begin{array}{l}\text { F: ACTTCCCCAGCCCTTACTACCG } \\
\text { R: TCAGCACATAGCCCACACCG }\end{array}$ & NM_007388.3 & 381 & $58^{\circ} \mathrm{C}$ & 30 \\
\hline Oscar & $\begin{array}{l}\text { F: CTGCTGGTAACGGATCAGCTCCCCAGA } \\
\text { R: CCAAGGAGCCAGAACCTTCGAAACT }\end{array}$ & NM_001290377.1 & 310 & $53^{\circ} \mathrm{C}$ & 35 \\
\hline $\begin{array}{l}\operatorname{Src} \\
(c-s r c)\end{array}$ & $\begin{array}{l}\text { F: TCCAGGCTGAGGAGTGGTACTTTGG } \\
\text { R: ATACGGTAGTGAGGCGGTGACACAG }\end{array}$ & NM_001025395.2 & 306 & $64^{\circ} \mathrm{C}$ & 40 \\
\hline $\begin{array}{l}M y c \\
(c-m y c)\end{array}$ & $\begin{array}{l}\text { F: CACCAGCAGCGACTCTGAAGAAGAG } \\
\text { R: AGAGGTGAGCTTGTGCTCGTCTGC }\end{array}$ & NM_001177352.1 & 505 & $64^{\circ} \mathrm{C}$ & 40 \\
\hline $\begin{array}{l}\text { Spil } \\
(P U-1)\end{array}$ & $\begin{array}{l}\text { F: CTTCCCTTATCAAACCTTGTC } \\
\text { R: AGGTGAGCTTCTTCTTGACTT }\end{array}$ & NM_011355.2 & 398 & $55^{\circ} \mathrm{C}$ & 30 \\
\hline $\begin{array}{l}\text { Ocstamp } \\
\text { (OC-Stamp) }\end{array}$ & $\begin{array}{l}\text { F: AGCTGTAGCCTGGGCTCAGAAG } \\
\text { R: AGCCTGTGGTAGATGACAGTCGTG }\end{array}$ & NM_029021.1 & 196 & $64^{\circ} \mathrm{C}$ & 45 \\
\hline Atp6v0d2 & $\begin{array}{l}\text { F: ATGGGGCCTTGCAAAAGAAATCTG } \\
\text { R: CGACAGCGTCAAACAAAGGCTTGTA }\end{array}$ & NM_175406.3 & 504 & $58^{\circ} \mathrm{C}$ & 30 \\
\hline Gapdh & $\begin{array}{l}\text { F: ACTTTGTCAAGCTCATTTCC } \\
\text { R: TGCAGCGAACTTTATTGATG }\end{array}$ & NM_008084.3 & 267 & $58^{\circ} \mathrm{C}$ & 30 \\
\hline
\end{tabular}

Runx2, runt-related transcription factor 2; ALP, Alkaline phosphatase; OSN, osteonectin; $O P N$, osteopontin; COL1, type I collagen; BSP, bone sialoprotein; Nfatc1, nuclear factor of activated T-cells cytoplasmic 1; Mmp-9, matrix metallopeptidase-9; Ctsk, cathepsin K; RANK, receptor activator of the nuclear factor kappa B; TRAP, tartrate-resistant acid phosphatase; Oscar, osteoclast-associated immunoglobulin-like receptor; Ocstamp, osteoclast stimulatory transmembrane protein; Atpv06d2, ATPase H+ transporting V0 subunit d2; Gapdh, glyceraldehyde 3-phosphate dehydrogenase.

on day 9 and the right femurs were extracted and analyzed by micro-computed tomography (micro-CT; SkyScan1176; SkyScan; Bruker Corp.). Bone volume/total volume (BV/TV), trabecular pattern factor (Tb.pf) and structure model index (SMI) calculations were performed using
NRecon software (SkyScan version 1.6.10.1; SkyScan; Bruker Corp.).

Statistical analysis. The experiments were repeated at least 3 times. The results are presented as the means \pm standard error 

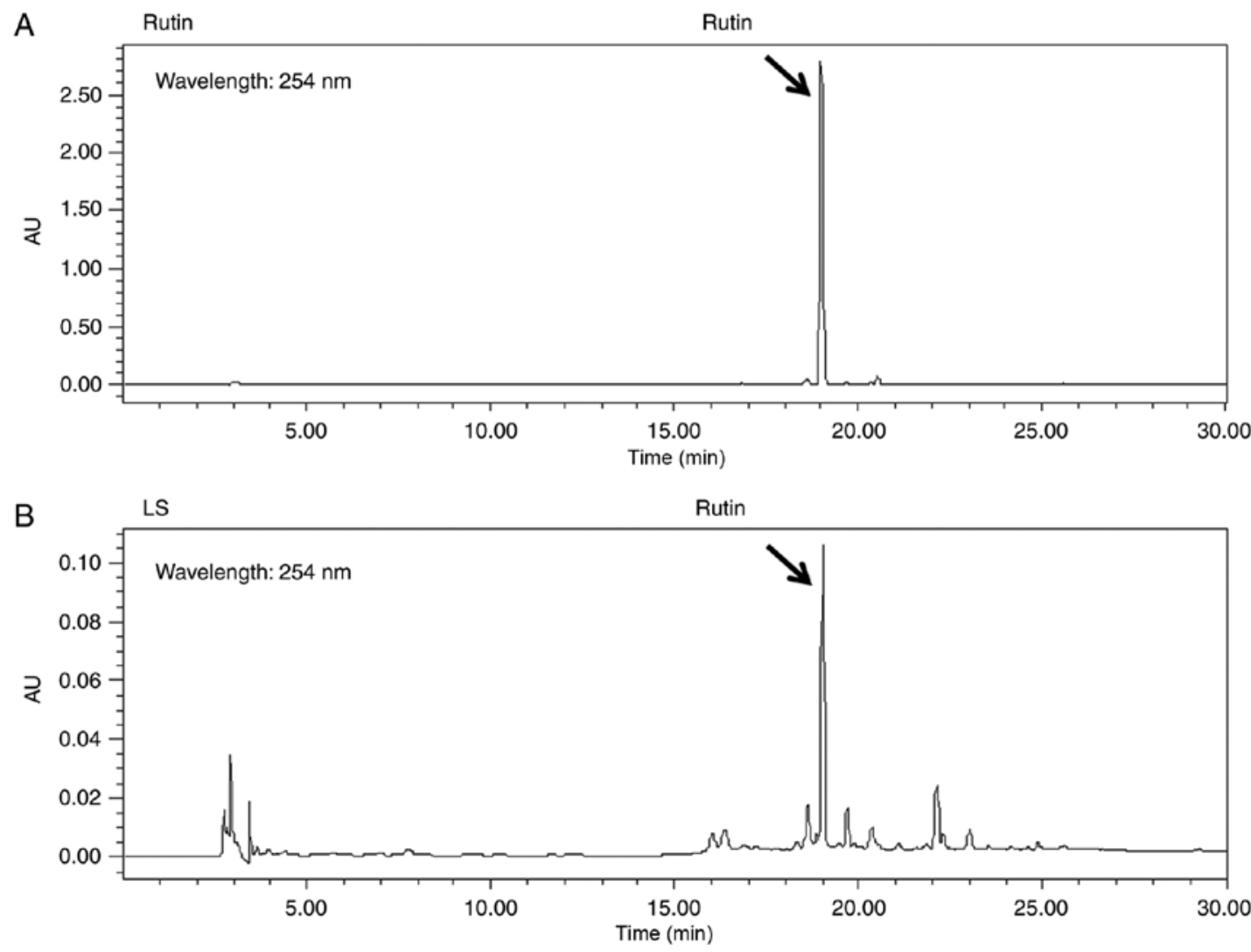

Figure 1. High-performance liquid chromatography chromatograms of (A) rutin and (B) Leonurus sibiricus L. Standard peaks for rutin were detected at $254 \mathrm{~nm}$.

of the mean. Statistical comparisons were performed one-way ANOVA tests, followed by Dunnett's post hoc analysis. A value of $\mathrm{P}<0.05$ was considered to indicate a statistically significant difference.

\section{Results}

Quantitative analysis of the LS extract. Rutin is a bioactive marker compound used for the validation of LS. The chromatogram of the ethanol extract from LS demonstrated that a number of peaks were detected at a retention time of 0 and $30 \mathrm{~min}$, and rutin was identified at the same retention time as the standards (Fig. 1).

LS treatment significantly increases osteoblast differentiation and promotes calcified nodule formation. LS at a concentration of 400 and $800 \mu \mathrm{g} / \mathrm{ml}$ was toxic to the MC3T3-E1 cells for 3, 7 and 14 days (Fig. 2A). Subsequently, to investigate the effects of LS on osteoblast differentiation, the MC3T3-E1 cells were treated with LS, ascorbic acid and $\beta$-glycerophosphate. Following 14 days of culture, Von Kossa and Alizarin Red S staining confirmed that calcified nodules were formed at an earlier stage in the LS treatment group when compared with the differentiated medium-treated group (Fig. 2B and C). At 17 and 21 days, LS enhanced osteoblast differentiation, as indicated by the increase in mineralized nodule formation. In addition, the absorbance of the extracted Alizarin Red S dye was increased by LS treatment (Fig. 2D). No significant difference was observed in osteoblast differentiation with
LS at 50 to $200 \mu \mathrm{g} / \mathrm{ml}$. Thus, the highest concentration was determined to be $50 \mu \mathrm{g} / \mathrm{ml}$ (data not shown). To determine the mechanisms of action of LS as regards osteoblast differentiation, the expression levels of transcription factors and osteogenic genes were analyzed in LS-treated osteoblasts. BMP-2 and RUNX2 are major transcription factors involved in osteoblast differentiation, and LS was observed to increase the expression levels of these genes (Fig. 2E and F). In addition, LS promoted the expression of osteogenic genes, including RUNX2, ALP ( $A l p l)$, OPN (Sparc), OSN (Sppl) and COL1 (Collal). BSP (Ibsp) expression increased with LS treatment, although the difference was not statistically significant (Fig. 2G and $\mathrm{H}$ ).

LS inhibits osteoclast differentiation at non-cytotoxic concentrations. Before confirming the osteoclast experiments, the toxicity of LS in the RAW 264.7 cells was confirmed. A high concentration $(800 \mu \mathrm{g} / \mathrm{ml})$ of LS reduced cell viability to below $50 \%$ and the concentrations of LS used in the osteoclast experiments did not affect the level of cytotoxicity (Fig. 3A and B). Thus, the possibility that the inhibition of osteoclast formation was due to cytotoxicity was excluded. To confirm the inhibitory effects of LS on osteoclastogenesis, TRAP staining and pit formation assays were performed. As demonstrated in Fig. 3C, the number of TRAP-positive osteoclasts was increased following stimulation of the cells with RANKL, and LS decreased the number and size of osteoclasts in a dose-dependent manner (Fig. 3D). In addition, LS inhibited TRAP activity in the differentiation medium (Fig. 3E). No 
A

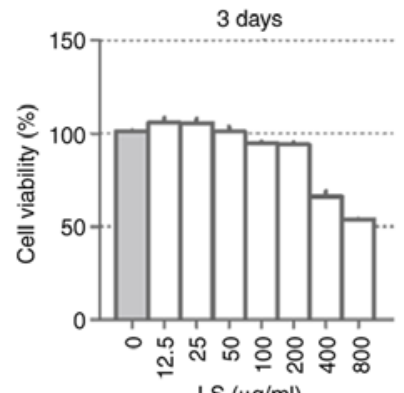

B

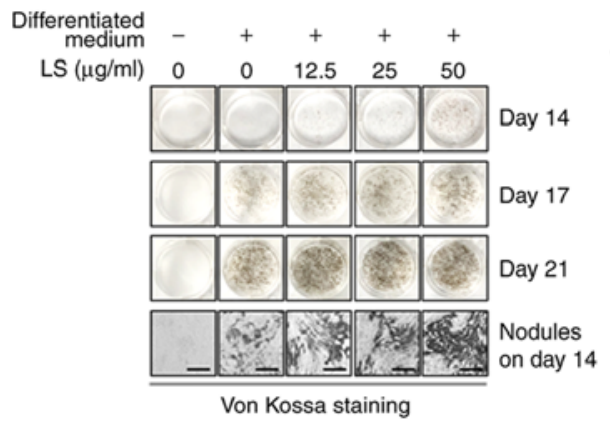

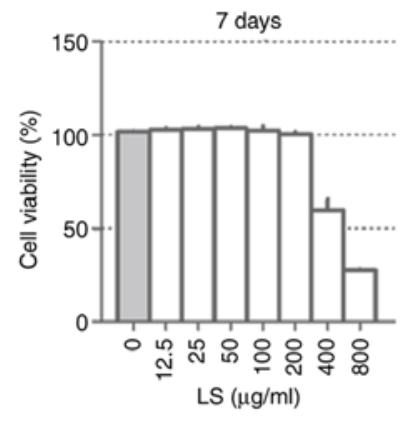

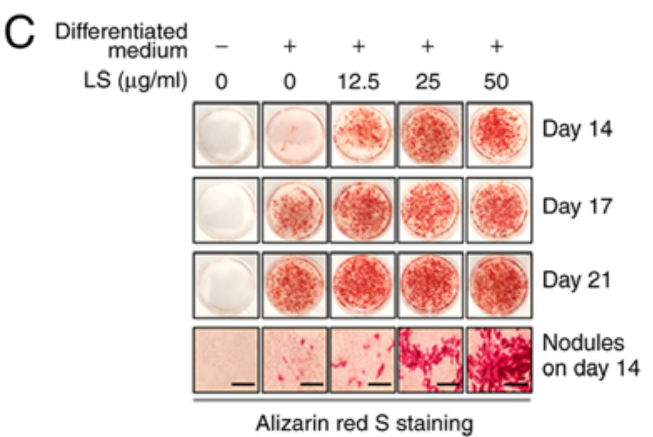

14 days
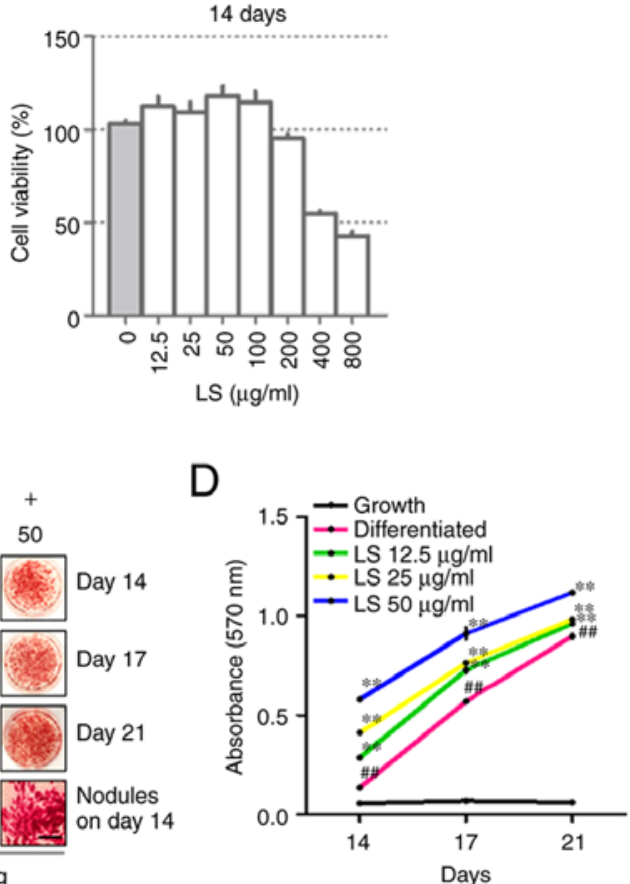

E

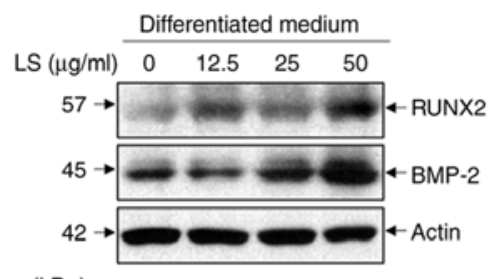

(kDa)
F

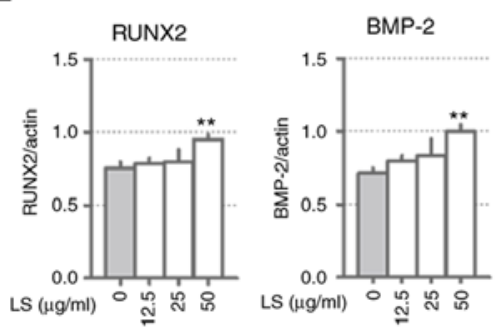

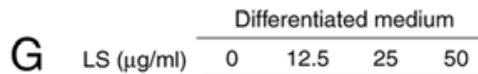
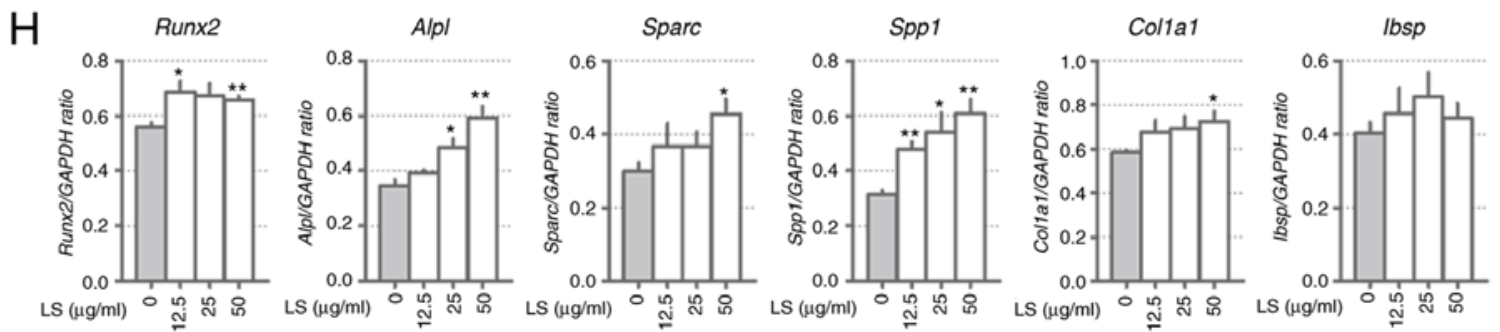

Figure 2. Effect of LS on osteoblast differentiation. (A) Cytotoxicity of LS used in osteoblast promotion assays was confirmed using an MTS assay for 3, 7 and 14 days. Calcified nodules produced by osteoblasts were stained with (B) Von Kossa and (C) Alizarin Red S (x100 magnification; scale bar, $200 \mu \mathrm{m}$ ) (D) Alizarin Red S stain was extracted from the cells and quantified by measuring the absorbance at $570 \mathrm{~nm}$. The effect of LS on the expression of transcription factors involved in osteoblast differentiation was also determined. (E) Protein expression of RUNX2 and BMP-2 were examined by western blot analysis (F) The protein expression levels of each marker were normalized to actin. (G) mRNA levels of RUNX2, ALP (alpl), OPN (Spp1), OSN (Sparc), COL1 (Collal) and BSP (Ibsp) were analyzed using reverse transcription semi-quantitative PCR. (H) The mRNA expression levels of each factor was normalized to GAPDH. The results are presented as the means \pm standard error of the mean $(\mathrm{n}=3)$. ${ }^{* \#} \mathrm{P}<0.01$ vs. growth cells; ${ }^{*} \mathrm{P}<0.05$ and ${ }^{* * *} \mathrm{P}<0.01$ vs. differentiated cells. LS, Leonurus sibiricus L.; RUNX2, runt-related transcription factor 2; BMP-2, bone morphogenetic protein 2; ALP, alkaline phosphatase; OPN, osteopontin; OSN, osteonectin; COL1, type I collagen; BSP, bone sialoprotein.

significant difference was observed in the inhibitory effects on osteoclastogenesis with LS at 100 to $400 \mu \mathrm{g} / \mathrm{ml}$. Thus, the highest concentration was determined to be $100 \mu \mathrm{g} / \mathrm{ml}$.

$L S$ inhibits bone resorptive activity. To evaluate the inhibitory effects of LS on resorptive activity, differentiated osteoclasts formed resorption pits through calcium absorption (Fig. 4A), and the area of the resorption pit was reduced by LS treatment
(Fig. 4B). RANKL stimulation increased the formation of the well-polarized F-actin ring (Fig. 4C). However, LS was observed to decrease both the size and number of F-actin ring structures (Fig. 4D).

$L S$ inhibits the activation of NF- $\kappa B$ and the phosphorylation of MAPKs. When osteoclast differentiation is induced by RANKL, the NF- $\kappa B$ and MAPKs signaling pathways are 
A

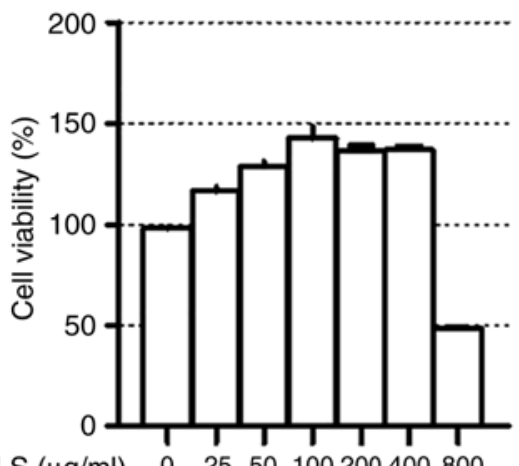

LS $(\mu \mathrm{g} / \mathrm{ml}) \quad 0 \quad 2550100200400800$
C

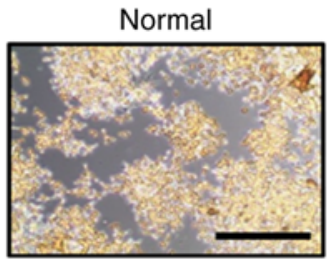

LS $50 \mu \mathrm{g} / \mathrm{ml}$

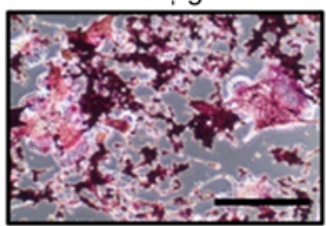

D

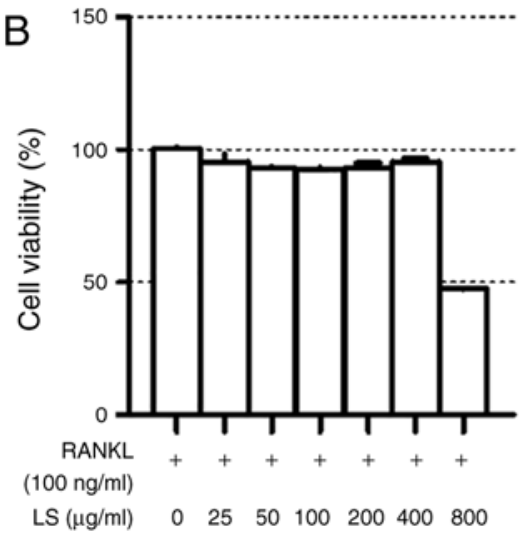

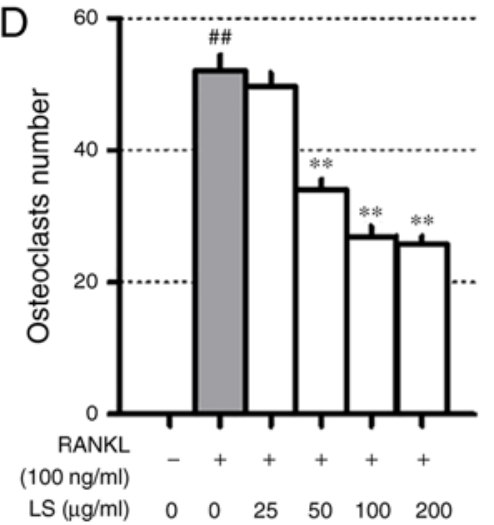

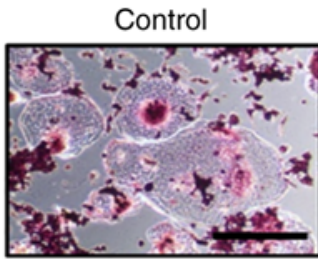

LS $100 \mu \mathrm{g} / \mathrm{ml}$

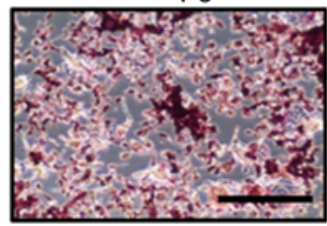

LS $25 \mu \mathrm{g} / \mathrm{ml}$

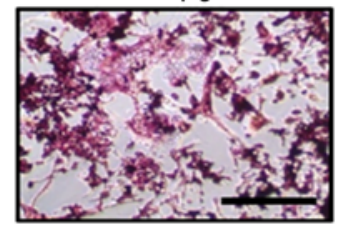

LS $200 \mu \mathrm{g} / \mathrm{ml}$

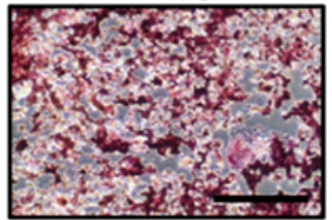

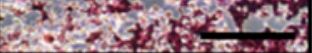

Figure 3. Effect of LS on osteoclast differentiation. Cytotoxicity of LS used in osteoclast inhibition assays was confirmed by MTS. (A) Cells were treated with LS alone for $24 \mathrm{~h}$ or (B) LS in the presence of RANKL for 5 days. (C) RANKL-induced osteoclasts were fixed and stained using a TRAP staining kit (100X magnification, Scale bar: $200 \mu \mathrm{m}$ ). (D) TRAP-positive giant cells with $\geq 3$ nuclei were considered as osteoclasts. (E) TRAP activity in the culture medium was measured at an absorbance of $405 \mathrm{~nm}$. The results are presented as the means \pm standard error of the mean $(\mathrm{n}=3)$. ${ }^{\# \#} \mathrm{P}<0.01 \mathrm{vs}$. normal; ${ }^{*} \mathrm{P}<0.05$ and ${ }^{* *} \mathrm{P}<0.01$ vs. RANKL-induced control. LS, Leonurus sibiricus L.; TRAP, tartrate-resistant acid phosphatase; RANKL, receptor activator of nuclear factor $\mathrm{k}$-B ligand.
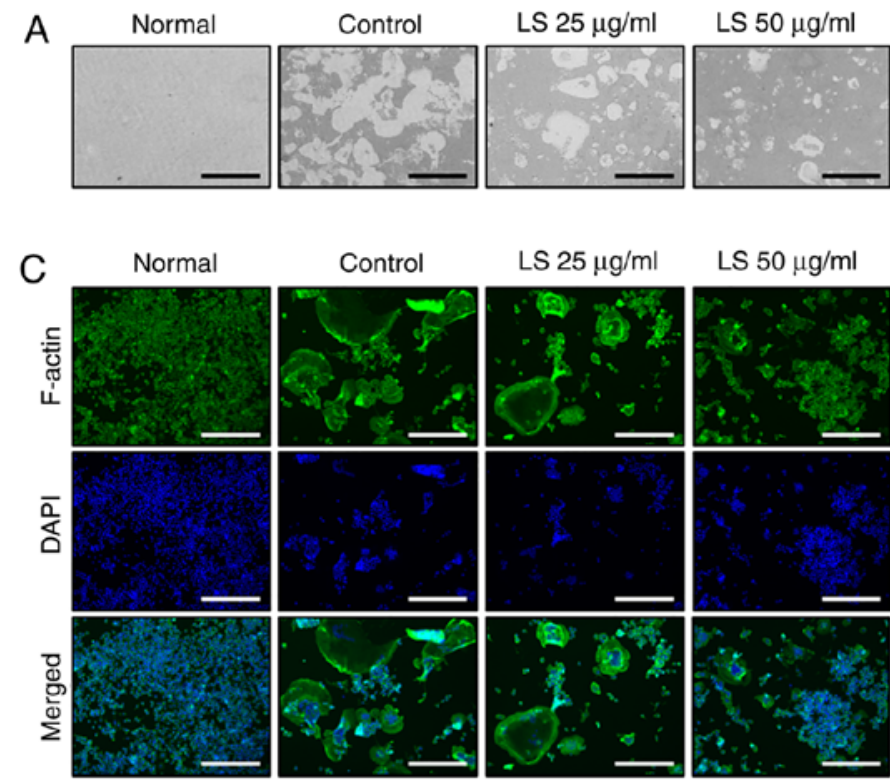

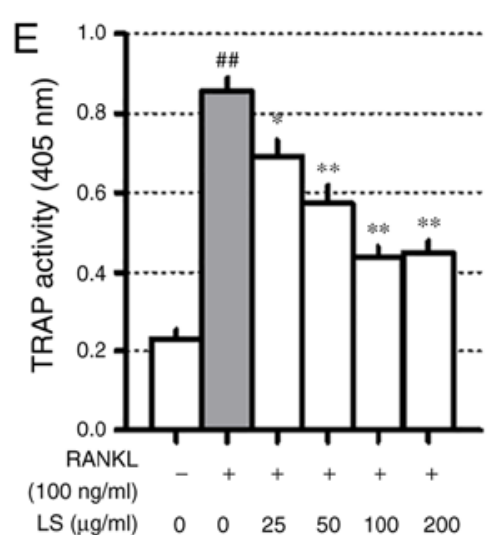

$(100 \mathrm{ng} / \mathrm{ml})$

LS $(\mu g / \mathrm{min}$

\section{d with
(100X
m was
e0.01
gand.}

$\mathrm{B}$
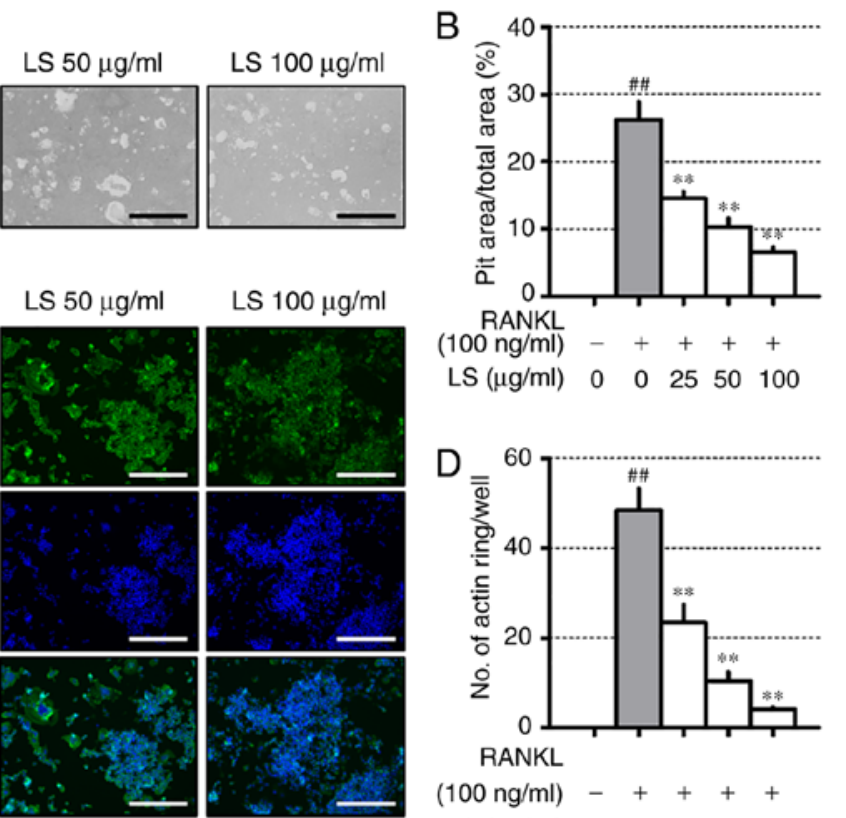

LS $100 \mu \mathrm{g} / \mathrm{ml}$

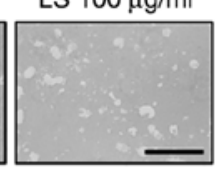

LS $100 \mu \mathrm{g} / \mathrm{ml}$

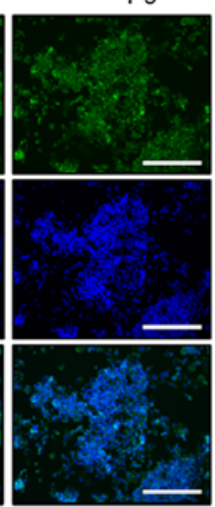

RANK

LS $(\mu \mathrm{g} / \mathrm{ml}) \quad 0 \quad 0 \quad 25 \quad 50 \quad 100$

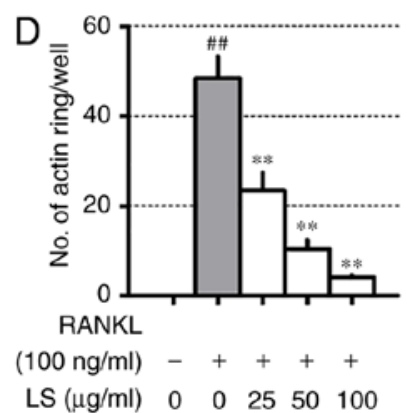

Figure 4. Effect of LS on pit formation and F-actin ring. (A) Inhibition of osteoclastic bone resorption by LS was assessed in osteo-coated plates (x100 magnification; scale bar, $200 \mu \mathrm{m}$ ). (B) The area of resorptive pits was measured using ImageJ software. (C) RANKL-induced F-actin were stained using a fluorescent phalloidin (x100 magnification; scale bar, $200 \mu \mathrm{m}$ ). (D) The number of F-actin rings was measured using ImageJ software. The results are presented as the means \pm standard error of the mean $(\mathrm{n}=3) .{ }^{\#} \mathrm{P}<0.01$ vs. normal; ${ }^{* *} \mathrm{P}<0.01$ vs. RANKL-induced control. LS, Leonurus sibiricus L.; F-actin, filamentous actin; RANKL, receptor activator of nuclear factor $\kappa$-B ligand. 

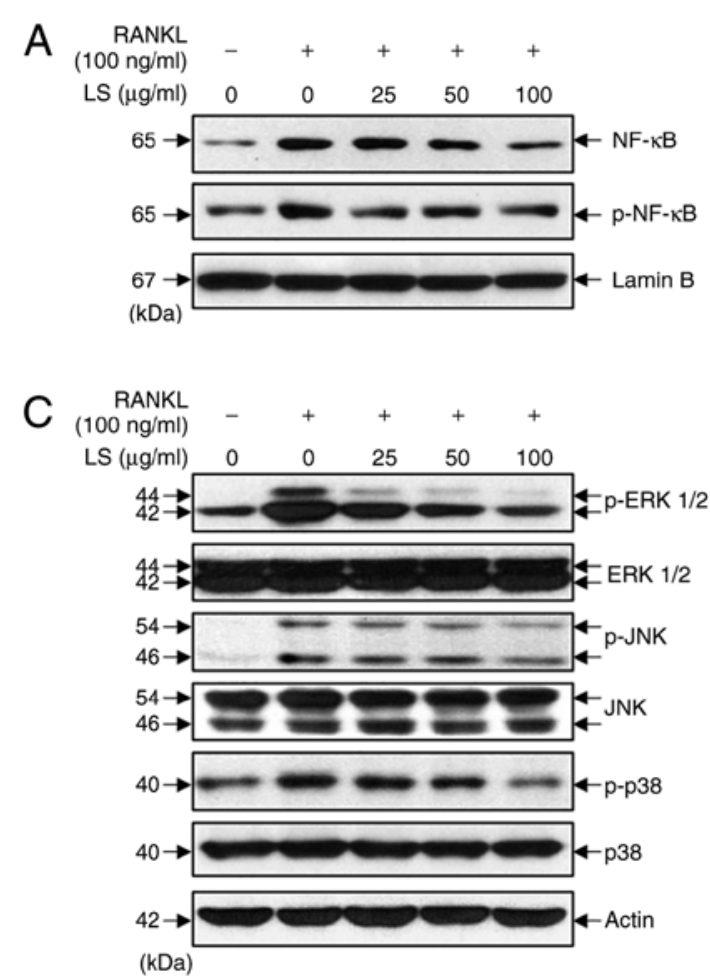

B

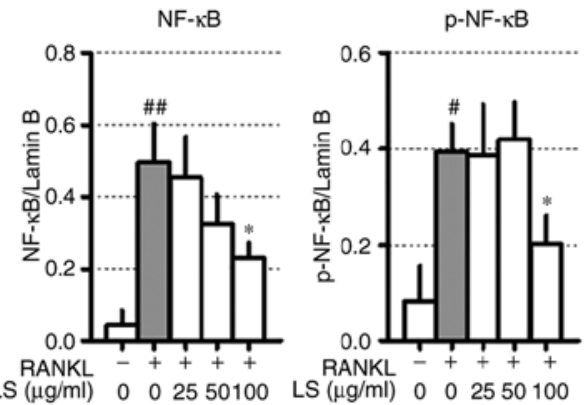

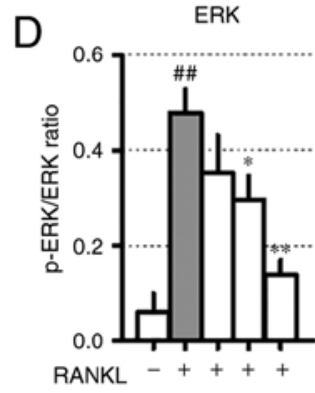

LS $(\mu \mathrm{g} / \mathrm{ml}) \quad 0 \quad 0 \quad 2550100$

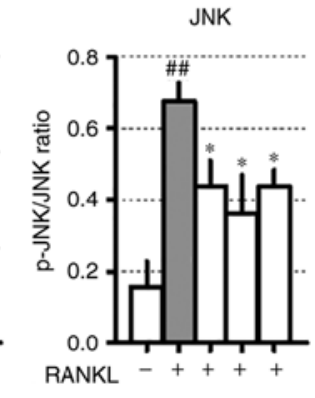

LS $(\mu \mathrm{g} / \mathrm{ml}) \quad 0 \quad 02550100$

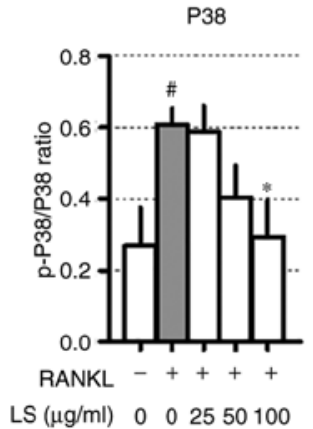

Figure 5. Effect of LS on the expression of NF- $\mathrm{kB}$ and MAPK signaling pathways. (A) Protein expression of NF- $\mathrm{kB}$ and p-NF- $\mathrm{kB}$ were measured by western blot analysis. (B) NF-kB and p-NF-kB expression was normalized to lamin B. (C) Protein expression of MAPKs were measured by western blot. (D) The expression of p-ERK1/2, p-JNK and p-p38 were normalized to total ERK1/2, JNK and p38, respectively. The results are presented as the means \pm standard error of the mean $(\mathrm{n}=3) .{ }^{\#} \mathrm{P}<0.05$ and ${ }^{\# \#} \mathrm{P}<0.01$ vs. normal; ${ }^{\mathrm{P}} \mathrm{P}<0.05$ and ${ }^{* *} \mathrm{P}<0.01$ vs. RANKL-induced control. LS, Leonurus sibiricus $\mathrm{L}$.; NF- $\mathrm{kB}$, nuclear factor- $\mathrm{kB}$; MAPKs, mitogen-activated protein kinases; p-, phosphorylated; ERK1/2, extracellular signal-regulated kinase 1/2; JNK, c-Jun N-terminal kinase; RANKL, receptor activator of nuclear factor $\mathrm{\kappa}-\mathrm{B}$ ligand.

essential. RANKL stimulation increases the protein levels of $\mathrm{NF}-\kappa \mathrm{B}$ and $\mathrm{p}-\mathrm{NF}-\kappa \mathrm{B}$. In this study, LS was observed to decrease the translocation of $N F-\kappa B$ to the nucleus and inhibit the phosphorylation of NF- $\kappa \mathrm{B}$ (Fig. $5 \mathrm{~A}$ and $\mathrm{B}$ ). In addition, LS treatment significantly inhibited the RANKL-induced phosphorylation of ERK1/2, JNK and p38 in a concentration-dependent manner (Fig. 5C and D).

LS inhibits the expression of essential transcription factors involved in osteoclastogenesis. To determine the mechanisms underlying LS-mediated osteoclast inhibition, the expression of NFATc1 and c-Fos was measured by western blot analysis and reverse transcription-semi-quantitative PCR. As demonstrated in Fig. 6, RANKL stimulation increased the protein and mRNA levels of $N f a t c l$ and FOS, whereas LS suppressed the expression of these factors. In addition, LS did not affect the expression of housekeeping genes, such as actin and GAPDH.

LS inhibits the expression of bone resorption markers and osteoclastogenesis-associated markers. To examine whether LS inhibits bone resorption-related enzymes, the effects of LS on the expression of MMP-9 and Ctsk were examined by western blot analysis and reverse transcription-semi-quantitative PCR. As demonstrated in Fig. 7A-D, RANKL stimulation induced the protein and mRNA expression levels of Mmp-9 and $C t s k$, whereas LS markedly suppressed the expression of these bone resorption-related enzymes. In addition, the effects of LS on markers involved in osteoclast differentiation were analyzed. As demonstrated in Fig. 7E and F, the expression of RANK (Tnfrsflla), TRAP (Acp5), OSCAR, c-src, c-myc, PU-1 (Spil), OC-STAMP and ATP6v0d2 was increased by RANKL treatment, whereas LS significantly inhibited the expression of these genes.

Administration of LS inhibits LPS-induced inflammatory bone loss. The results presented thus far indicated that LS activated osteoblast differentiation and inhibited osteoclast differentiation. To confirm these in vitro results, the potential inhibitory effects of LS on bone loss in vivo were investigated. The concentration of LS administered in this study was determined as follows: In oriental medicine, based on a typical adult weight of $60 \mathrm{~kg}$, a single dose of LS is $8 \mathrm{~g}$ and corresponding to $0.6184 \mathrm{~g}$ (yield, $7.73 \%$ ) of LS extract. Therefore, $10.3 \mathrm{mg}$ of LS should be administered per $1 \mathrm{~kg}$. In previous studies, mice are known to have a 7-fold higher metabolism than humans (20), and an LS dose of approximately $72 \mathrm{mg} / \mathrm{kg}$ is appropriate. In this study, LS was administered at a slightly higher concentration than that administered to humans. To achieve this, a mouse model of endotoxin-induced bone destruction was first generated $(21,22)$. The following day after LPS administration, the weight of the mice was reduced, but this was recovered. In addition, no marked changes in body weight due to LS were observed (Fig. S1). As demonstrated in Fig. 8A, micro-CT images of the femur indicated a decrease in trabecular bone; however, the administration of LS significantly inhibited LPS-induced bone loss. Based on the radiographic results, 

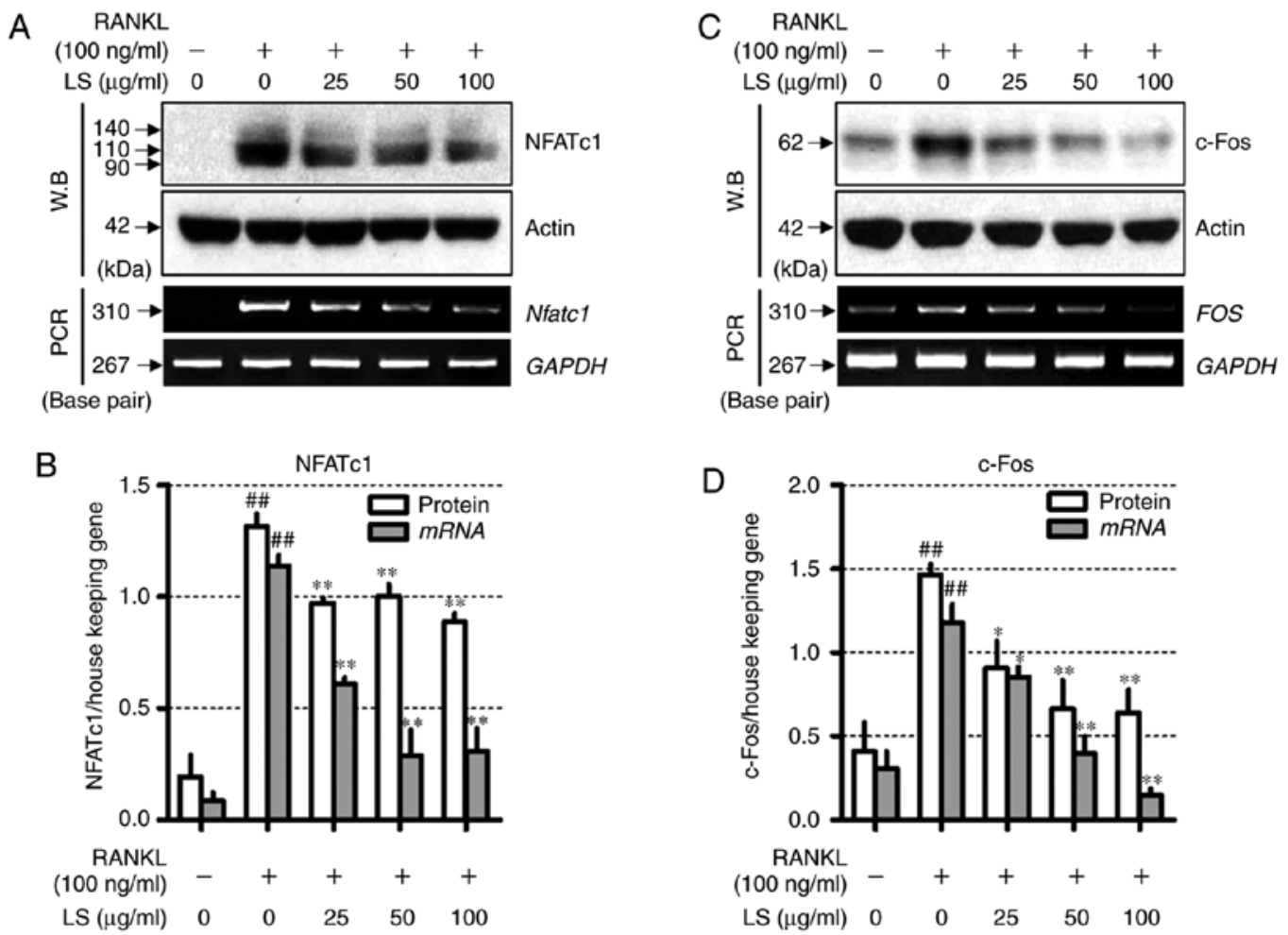

Figure 6. Effect of LS on the expression of essential transcription factors involved in osteoclastogenesis. (A) Expression of NFATc1 was measured by western blot and RT-PCR. (B) Protein and mRNA expression of NFATc1 was normalized to actin and GAPDH, respectively. (C) Expression of c-Fos was detected by western blot analysis and reverse transcription semi-quantitative PCR. (D) Protein and mRNA levels of c-Fos was normalized to actin and GAPDH, respectively. The results are presented as the means \pm standard error of the mean $(\mathrm{n}=3)$. ${ }^{\# \#} \mathrm{P}<0.01$ vs. normal; ${ }^{*} \mathrm{P}<0.05$ and ${ }^{* * *} \mathrm{P}<0.01$ vs. RANKL-induced control. LS Leonurus sibiricus L.; NFATc1, nuclear factor of activated T-cells 1; RANKL, receptor activator of nuclear factor $\kappa$-B ligand.

the effect of LS on bone microstructure was also analyzed. This revealed that LPS administration reduced bone mineral density (BMD) and BV/TV, whereas the administration of LS significantly inhibited the LPS-induced reduction in BMD and BV/TV. In addition, the LPS-induced increase in Tb.pf was suppressed by LPS treatment. Similarly, SMI increased with LPS administration, which was suppressed by treatment with LS; however, the difference was not statistically significant (Fig. 8B-E).

Based on the results of this study, LS promoted osteogenic gene expression by upregulating RUNX2 in MC3T3-E1 cells. In addition, LS inhibited the bone resorption gene by inhibiting the expression of NFATc1/c-Fos in RANKL-induced RAW 264.7 cells. As a result, it exerted an anti-osteoporotic effect in mice with LPS-induced bone less (Fig. 9).

\section{Discussion}

Bone metabolic disease is characterized by the abnormal activity of osteoclasts. To solve this problem, researchers have investigated natural products that activate osteoblasts or exert inhibitory effects on osteoclastogenesis (23). Although the ethanol extract of LS on osteoporosis has not been studied to date, the study by Yang et al demonstrated that leonurine hydrochloride, which is component of LS, promoted osteogenic differentiation (24). However, their study did not proceed onto investigating osteoclastogenesis. In osteoblast differentiation, RUNX2 induction through the Wnt/b-catenin mechanism is the main focus of research. On the contrary, this study investigated the effects of LS on osteoblasts and osteoclasts, and the promotion of osteoblast differentiation was the result of the upregulation of BMP-2 and RUNX2. To the best of our knowledge, this study is also the first LS study of bone destruction due to chronic inflammation. Two cell models were used to determine the effects of LS on osteoblasts and osteoclasts. MC3T3-E1 cells are derived from the bone/calvaria of C57BL/6 mice and are a well-known osteoblast-like cell line. These cells are useful to the research of the molecular mechanisms of osteoblasts and provide a model for studying bone cell differentiation and proliferation (25). The RAW 264.7 murine cell line is suitable for establishing a RANKL-induced osteoclast experimental model (26).

Mineralization nodules are one of the biomarkers that determine osteoblast maturation, and can be detected by Von Kossa and Alizarin S Red staining $(27,28)$. In the current study, the formation of calcified nodules following induction by ascorbic acid and $\beta$-glycerophosphate was increased by LS treatment. BMP-2 is a transcription factor that regulates typical osteoblast differentiation and bone formation (29). Once activated, it translocates into the nucleus to induce the expression of bone matrix proteins, such as RUNX2, ALP, BSP and COL1 (6). Among these, RUNX2 is essential for osteoblast differentiation, and is detected in pre-osteoblasts, where its expression increases as the cell develops into an immature osteoblast (7). Some studies have demonstrated that natural extracts can upregulate BMP-2/RUNX2 and promote osteoblast differentiation $(30,31)$. ALP and BSP is involved in early-stage molecular events during osteoblast differentiation and is 
A RANKL

$(100 \mathrm{ng} / \mathrm{ml})-++++$

LS $(\mu \mathrm{g} / \mathrm{ml}) \quad 0 \quad 0 \quad 25 \quad 50 \quad 100$

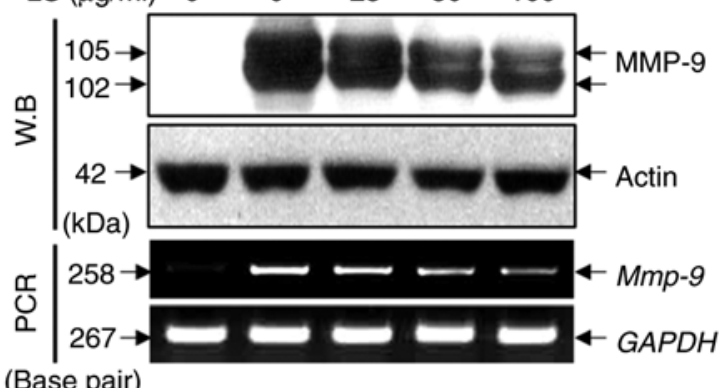

(Base pair)

B

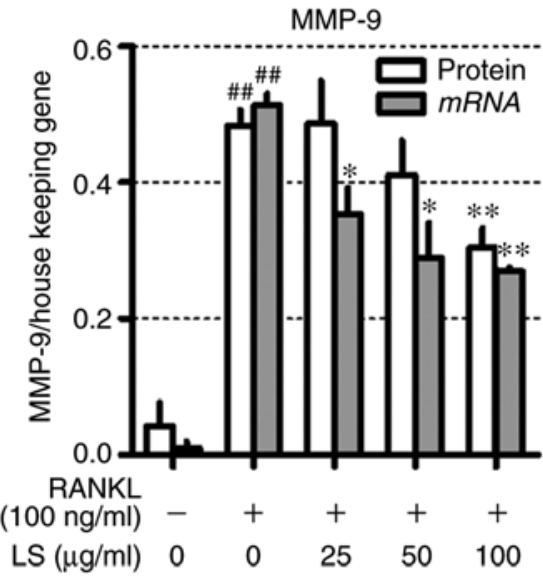

$\mathrm{E}$

RANKL

$(100 \mathrm{ng} / \mathrm{ml})-+\quad+\quad+\quad+$

LS $(\mu \mathrm{g} / \mathrm{ml}) \quad 0 \quad 0 \quad 0 \quad 25 \quad 50 \quad 100$

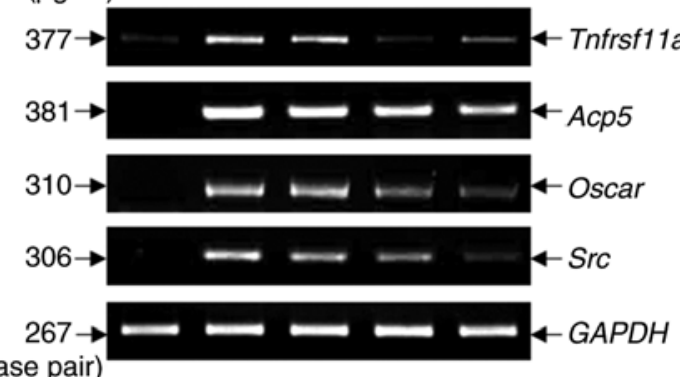

(Base pair)

$\mathrm{F}$

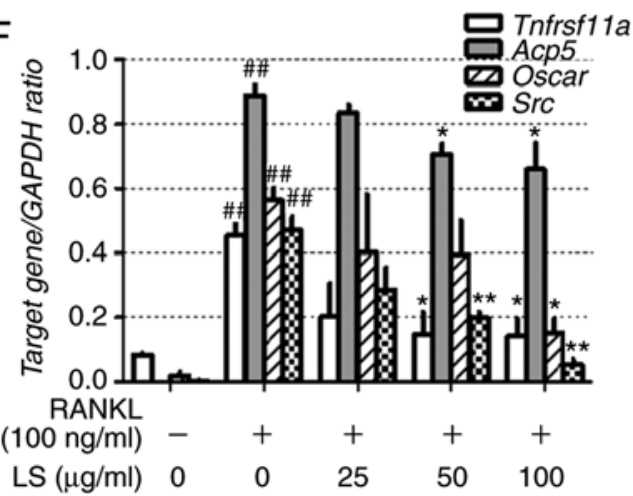

C RANKL

$(100 \mathrm{ng} / \mathrm{ml})-+++$

LS $(\mu \mathrm{g} / \mathrm{ml}) \quad 0 \quad 0 \quad 0 \quad 25 \quad 50 \quad 100$

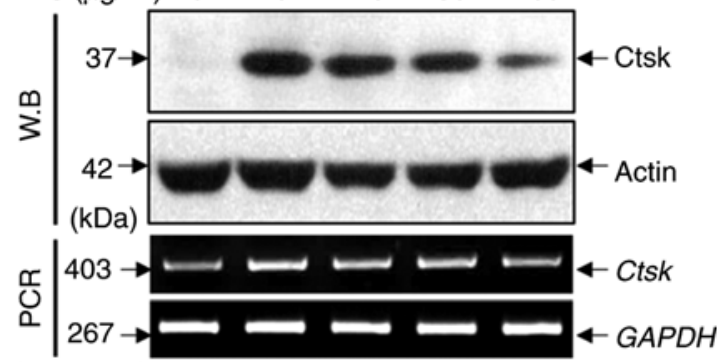

(Base pair)

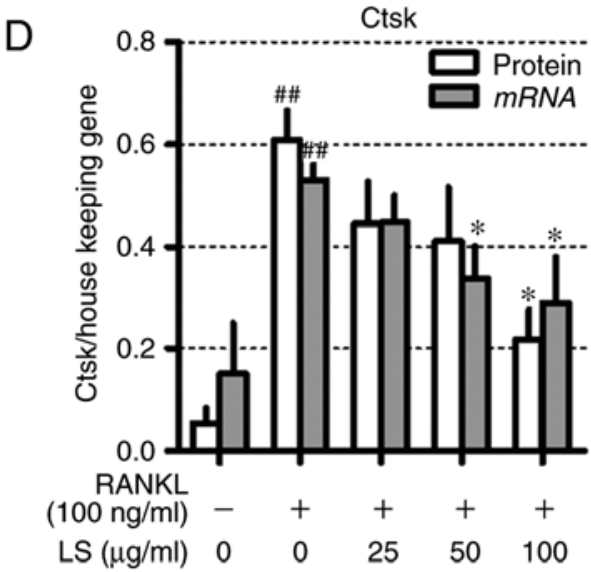

RANKL

$(100 \mathrm{ng} / \mathrm{ml})-+\quad+\quad+\quad+$

LS $(\mu \mathrm{g} / \mathrm{ml}) \quad 0 \quad 0 \quad 25 \quad 50 \quad 100$

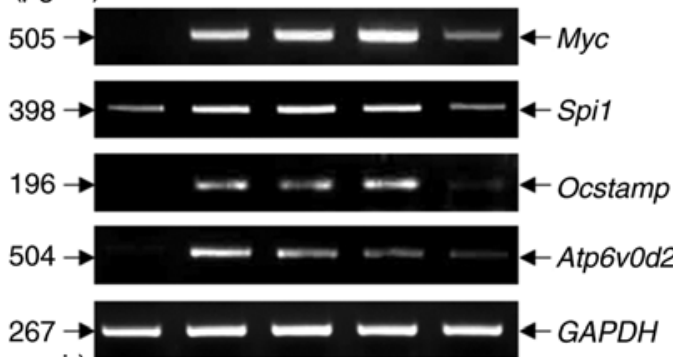

(Base pair)

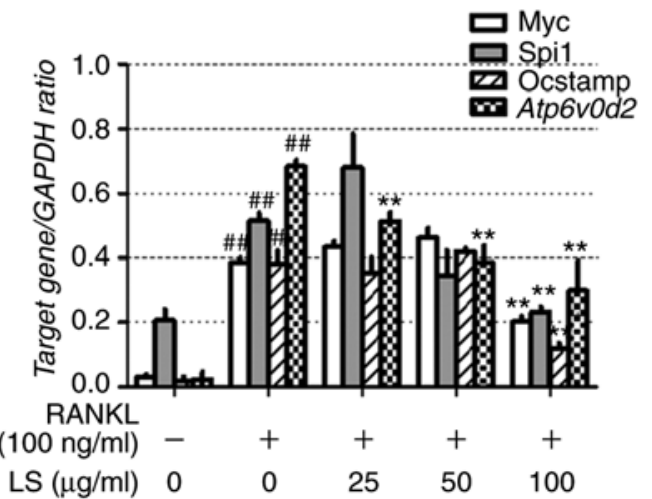

Figure 7. Effect of LS on the expression of osteoclastic bone resorption enzymes. (A) Expression of MMP-9 was measured by western blot analysis and RT-PCR analysis. (B) Protein and mRNA expression levels of MMP-9 were normalized to actin and GAPDH, respectively. (C) Expression of Ctsk was detected by western blot and reverse transcription semi-quantitative PCR. (D) Protein and mRNA expression of Ctsk was normalized to actin and GAPDH, respectively. (E) mRNA levels of RANK (Tnfrsf11a), TRAP (Acp5), OSCAR, c-src (Src), c-myc (Myc), PU-1 (Spi1), OC-STAMP and ATP6v0d2 were analyzed by reverse transcription semi-quantitative PCR on day 4. (F) The mRNA expression levels of each factor were normalized to GAPDH. The results are presented as the means \pm standard error of the mean $(\mathrm{n}=3)$. ${ }^{\# \prime} \mathrm{P}<0.01$ vs. normal; ${ }^{*} \mathrm{P}<0.05$ and ${ }^{* * *} \mathrm{P}<0.01$ vs. RANKL-induced control. LS, Leonurus sibiricus $\mathrm{L}$.; MMP-9, matrix metallopeptidase-9; Ctsk, cathepsin K; RANK, receptor activator of nuclear factor $\kappa$; TRAP, tartrate-resistant acid phosphatase; OSCAR, osteoclast-associated immunoglobulin-like receptor; OC-STAMP, osteoclast stimulatory transmembrane protein; ATP6v0d2, ATPase H+ transporting V0 subunit d2; RANKL, receptor activator of nuclear factor $\kappa-\mathrm{B}$ ligand. 


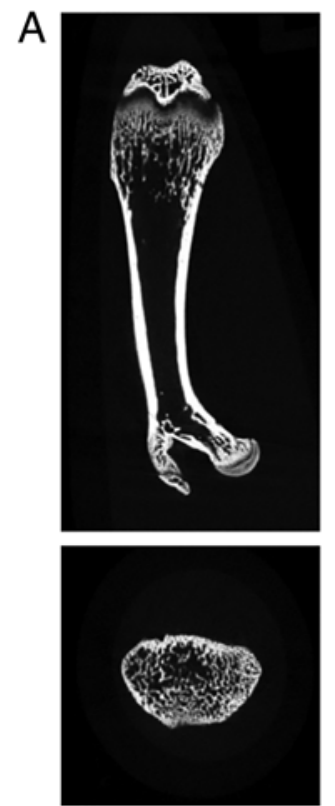

Sham
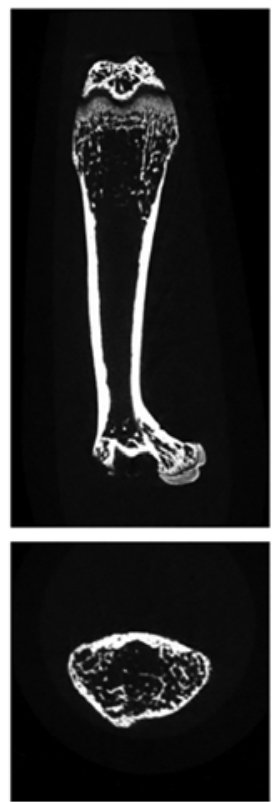

LPS
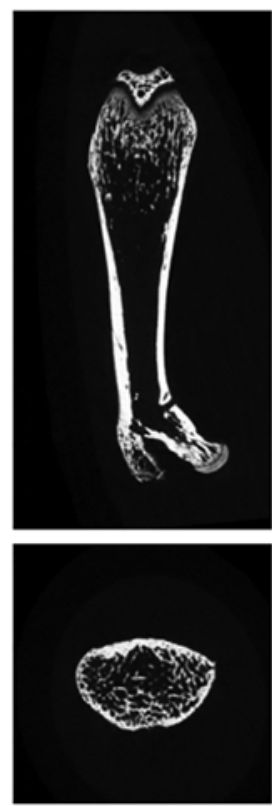

LPS+LS

$(100 \mathrm{mg} / \mathrm{kg})$

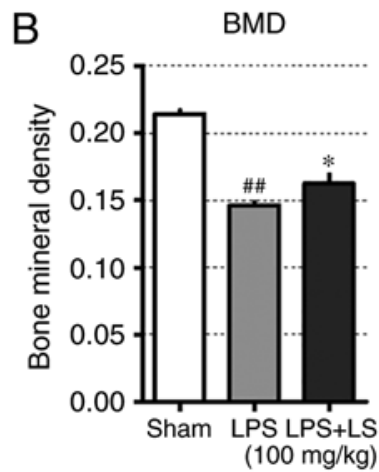

C
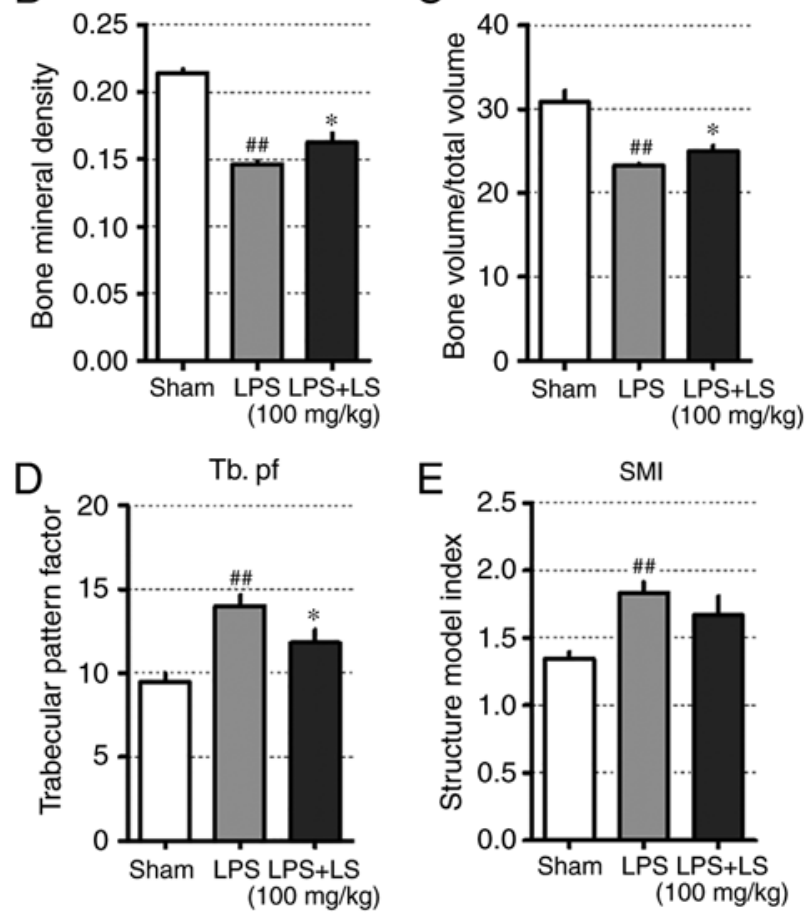

Figure 8. Effect of LS on LPS-induced bone destruction. Six-week-old Institute of Cancer Research mice were injected with LPS intraperitoneally at 1 and 4 days. LS was administered orally each day for a total of 9 days. (A) The longitudinal and transverse of femur was scanned using micro-CT. Graphical representation of (B) BMD, (C) BV/TV, (D) Tb. pf and (E) SMI. The results are presented as the mean \pm standard error of the mean ( $\mathrm{n}=6$ mice). ${ }^{\# \#} \mathrm{P}<0.01$ vs. sham; "P<0.05 vs. RANKL-induced control. LS, Leonurus sibiricus L.; LPS, lipopolysaccharide; micro-CT, micro-computed tomography; BMD, bone mineral density; BV/TV, bone volume/total volume; Tb. pf, trabecular pattern factor; SMI, structure index model.

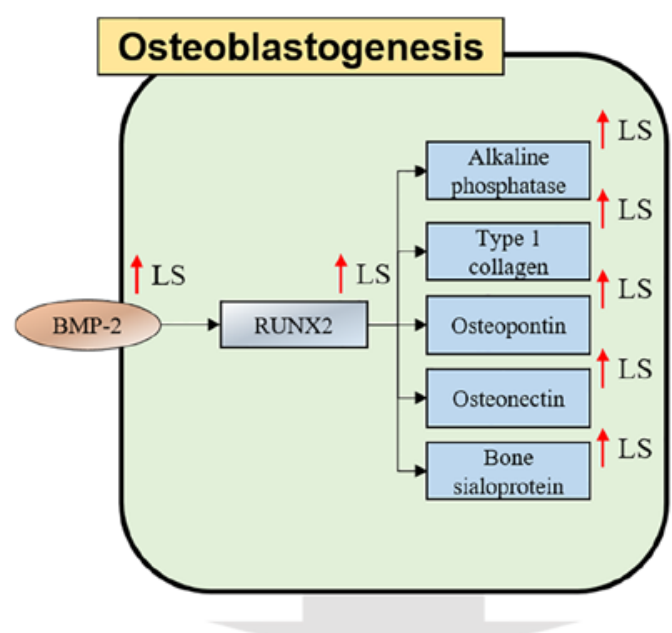

Promotive effect of osteoblastogenesis

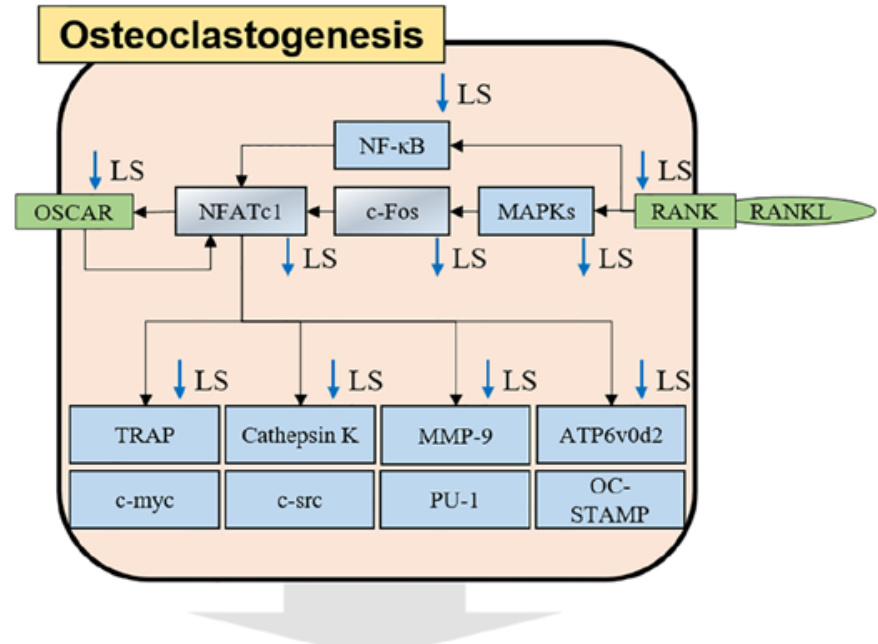

Inhibitory effect of osteoclastogenesis

\section{Anti-osteoporosis effects}

Figure 9. Mechanisms of osteoblasts and osteoclasts in LS. LS, Leonurus sibiricus L. BMP-2, bone morphogenetic protein 2; RUNX2, Runt-related transcription factor 2; OSCAR, osteoclast-associated immunoglobulin-like receptor; NFATc1, nuclear factor of activated T-cells 1; TRAP, tartrate-resistant acid phosphatase; RANKL, receptor activator of nuclear factor- $\kappa \mathrm{B}$ ligand; MAPK, mitogen-activated protein kinase; NF- $\kappa \mathrm{B}$, nuclear factor- $\kappa \mathrm{B}$; MMP-9, matrix metallopeptidase-9; ATP6v0d2, ATPase $\mathrm{H}+$ transporting V0 subunit d2.

known to upregulate the initial mineralization stage $(32,33)$. OPN is known as a non-collagenous major bone matrix protein, and it is expressed when osteoblasts and osteocytes form bone, and plays an important role in bone regeneration. In 
particular, OPN enables osteoclasts to attach to the bone (34). Recently, the overexpression of OPN was observed to inhibit the expression of BMP-2-induced ALP and BSP, ultimately inhibiting osteoblast differentiation and mineralization (35). OSN is a glycoprotein that attaches to calcium in bone. This occurs when osteoblasts produce bone and initiate mineralization (36). In OSN-null mice, the number of osteoblasts and the rate of bone formation are decreased (37). COL1 expression is typically upregulated in the osteoblast differentiation and mineralization stages (38). The results of the current study demonstrated that LS upregulated the expression of BMP-2 and RUNX2, and markedly increased the expression of ALP, BSP, COL1, OPN and OSN. These results indicate that the effect of LS on promoting osteoblasts and the formation of mineralization nodules may be mediated via the activation of BMP-2, RUNX2 and osteogenic genes.

TRAP is known as an osteoclast phenotype marker and TRAP staining is the standard method used to detect osteoclast differentiation (39). In addition, TRAP expression is associated with differentiated osteoclast migration and also effects osteoclast differentiation and maturation. Mice lacking the TRAP gene are known to develop osteoporosis and display irregular bone microstructures (40). In the present study, LS inhibited RANKL-induced osteoclast differentiation and activity. The pit formation assay is used to measure the bone resorption ability of osteoclasts and an F-actin ring is the most visible feature of mature osteoclasts (41). The results of the current study also demonstrated that LS significantly inhibited pit formation in RANKL-induced osteoclasts. Taken together, these results suggest that LS inhibits osteoclast differentiation and impairs the function of mature osteoclasts.

$N F-\kappa B$ translocates to the nucleus via the binding of RANK-RANKL and is known to play a key role in the early stages of osteoclast development. Rats lacking NF- $\kappa \mathrm{B} 1$ and $\mathrm{NF}-\kappa \mathrm{B} 2$ are unable to differentiate into osteoclasts, which leads to osteopetrosis in rats (42). In addition to the NF- $\kappa \mathrm{B}$ signaling pathway, the MAPK signaling pathway is also known to play an important role in osteoclast differentiation. ERK is associated with osteoclast survival (43), and JNK-deficient rats are unable to differentiate into osteoclasts (44). Furthermore, p38 affects early osteoclastogenesis and plays an important role in the expression of Ctsk $(45,46)$. The present study confirmed that LS inhibited $\mathrm{NF}-\kappa \mathrm{B}$ expression and its phosphorylation in the nucleus. In addition, LPS suppressed the MAPK signaling pathway by inhibiting the phosphorylation of ERK, JNK and p38.

c-Fos is an established group of essential transcription factors involved in osteoclast differentiation (47). c-Fos, which is induced by binding of RANKL-RANKL, directly activates the expression of NFATc1. Mice deficient in c-fos exhibit defective osteoclast differentiation, which leads to osteopetrosis. NFATc1 is the master transcription factor involved in osteoclast differentiation; NFATc1-deficient embryonic stem cells are unable to differentiate into osteoclasts via RANKL (9). In addition, the ectopic expression of NFATc1 successfully promotes osteoclast differentiation even in the absence of RANKL (48). In the present study, LS inhibited the protein and gene expression levels of NFATc1 and c-Fos. This suggests that the inhibitory effect of LS on osteoclast differentiation may be due to the suppression of the essential transcription factors, NFATc1 and c-Fos.
As LS strongly inhibited NFATc1, it can thus be hypothesized that LS may also suppress the expression of NFATc1-regulated osteoclast-associated genes, including TRAP, MMP-9, Ctsk, ATP6v0d2 and OSCAR (9). MMP-9 and Ctsk are enzymes that are released when osteoclasts undergo bone resorption. MMP-9 is expressed in the early differentiation phase of osteoclasts and when mature osteoclasts absorb bone (49). In addition, Ctsk is essential for bone resorption, and osteoclasts extracted from Ctsk-deficient mice are unable to absorb bone (50). In the present study, LS was demonstrated to suppress osteoclast function by significantly inhibiting bone resorption-related enzymes. c-src is essential for ruffled border formation (51), c-myc is expressed early in osteoclast differentiation and induces other effector genes (52). PU-1 is induced by RANKL stimulation and up-regulates p38 and NFATc1 (53). In this study, LS inhibited the gene expression levels of c-src, c-myc and PU-1. OSCAR is specifically expressed in early stage osteoclasts or in mature osteoclasts, and induces calcium activation to assist in the expression of RANKL-mediated NFATc1 (54). Similar to these results, the majority of osteoclast inhibition studies have reported that osteoclast-related genes are decreased by reduction of c-Fos and NFATc1 $(55,56)$. OC-STAMP and ATP6v0d2 are expressed when the osteoclast precursor cells are fused, and when it is deficient, differentiation into osteoclasts is not completed. Moreover, these genes are essential for formation of F-actin ring (57,58). In the current study, LS suppressed the expression of ATP6v0d2 and OSCAR. These results suggest that LS inhibits MMP-9, Ctsk, OSCAR, c-src, c-myc, PU-1, OC-STAMP and ATP6v0d2 which serve important roles in osteoclast differentiation and activation via inhibition of NFATc1 (Fig. 9).

LPS-induced mouse models are commonly used to verify bone loss and bone destruction in chronic inflammatory conditions (59). However, the mechanisms underlying the activation of osteoclasts by LPS in vivo are unclear.LPS-induced inflammatory cytokines, such as tumor necrosis factor- $\alpha$, interleukin (IL)- $1 \beta$ and IL-6 are known to influence osteoclast differentiation (22). As demonstrated by the radiographic results in the current study, LS treatment significantly inhibited bone loss induced by LPS. This suggests that LS suppresses bone loss induced by LPS, and that this inhibitory effect may be due to the LS-mediated inhibition of osteoclast differentiation and osteoblast induction.

In conclusion, the effects of LS treatment on bone metabolism in the current study revealed a number of important results: i) LS was not cytotoxic to the MC3T3-E1 and RAW 264.7 cells; ii) LS enhanced osteoblast cells, leading to increased mineralization nodules; iii) LS induced the expression of osteogenic genes and RUNX2 and BMP-2 in osteoblast precursor cells; iv) LS inhibited osteoclast differentiation and function; v) LS suppressed the expression of NFATc1 and c-Fos; vi) LS suppressed the expression of MMP-9, CTK, OSCAR, c-src, c-myc, PU-1, OC-STAMP and ATP6v0d2; vii) LS regulated bone loss in inflammatory osteoporosis induced by LPS. Based on these results, LS may present a potential alternative for the treatment of bone metabolic diseases.

However, this study had the following limitations. i) The estrogenic activity of phenol-red in medium used for in vitro experiments was not considered (60).ii) It is also known that LS has estrogenic activity. Since estrogenic activity can promote 
osteoblast differentiation or inhibit osteoclast differentiation (61), in the future, cell experiments using phenol red-free medium and measurement of estrogen hormone changes in animal model should be studied. iii) The safety and side-effects of LS have not yet been elucidated $(62,63)$. In this experiment, LS did not affect the body weight and liver weight of the animals; however, further studies on high-dose and long-term administration are warranted. iv) Quantitative PCR was not used for mRNA analysis. Therefore, the amount of expression of the gene was not known, and the increase/decrease relative to control was found. v) Considering that LS is traditionally used in female-related diseases, it would be valuable to examine the effects of LS in post-menopausal osteoporosis models in the future.

\section{Acknowledgements}

Not applicable.

\section{Funding}

This study was supported by the National Research Foundation of Korea (NRF) grant funded by the Korea government (MSIT, 2017R1A2B4010163) and the Ministry of Education (2017R1D1A1B03028505).

\section{Availability of data and materials}

All data generated or analyzed during this study are included in this published article or are available from the corresponding author on reasonable request.

\section{Authors' contributions}

YS and HSJ conceptualized the study. JHK and MK performed all experiments and verified the analytical data. JHK and HSJ contributed to the statistical analysis and helped interpret the results. YS supervised the experiments in discussion with JHK and MK. JHK and MK wrote the manuscript. All authors have read and agreed on the final manuscript.

\section{Ethics approval and consent to participate}

All animal experiments proceeded with permission of the Kyunghee University Animal Committee [ref. no. KHUASP(SE)-15-095].

\section{Patient consent for publication}

Not applicable.

\section{Competing interests}

The authors declare that they have no competing interests.

\section{References}

1. Feng $\mathrm{X}$ and McDonald JM: Disorders of bone remodeling. Annu Rev Pathol 6: 121-145, 2011.

2. Colon-Emeric CS and Saag KG: Osteoporotic fractures in older adults. Best Pract Res Clin Rheumatol 20: 695-706, 2006.
3. Augoulea A, Tsakonas E, Triantafyllopoulos I, Rizos D, Armeni E, Tsoltos N, Tournis S, Deligeoroglou E, Antoniou A and Lambrinoudaki I: Comparative effects of denosumab or bisphosphonate treatment on bone mineral density and calcium metabolism in postmenopausal women. J Musculoskelet Neuronal Interact 17: 444-449, 2017.

4. Kennel KA and Drake MT: Adverse effects of bisphosphonates: Implications for osteoporosis management. Mayo Clin Proc 84: 632-637; quiz 638, 2009.

5. Miyazaki T, Tokimura F and Tanaka S: A review of denosumab for the treatment of osteoporosis. Patient Prefer Adhere 8: 463-471, 2014.

6. Liu T, Gao Y, Sakamoto K, Minamizato T, Furukawa K, Tsukazaki T, Shibata Y, Bessho K, Komori T and Yamaguchi A: BMP-2 promotes differentiation of osteoblasts and chondroblasts in Runx2-deficient cell lines. J Cell Physiol 211: 728-735, 2007.

7. Komori T: Regulation of osteoblast differentiation by Runx 2 . Adv Exp Med Biol 658: 43-49, 2010.

8. Boyce BF and Xing L: Functions of RANKL/RANK/OPG in bone modeling and remodeling. Arch Biochem Biophys 473: 139-146, 2008.

9. Kim JH and Kim N: Regulation of NFATc1 in osteoclast differentiation. J Bone Metab 21: 233-241, 2014.

10. Boyle WJ, Simonet WS and Lacey DL: Osteoclast differentiation and activation. Nature 423: 337-342, 2003.

11. Herbology Editorial Committee of Korean Medicine: Herbology. Younglimsa, Seoul, pp 460-461 2004 (In Korean).

12. Kim DH, Kim HM, Ryu JH, Um JY, Kim SC and Yang JH (Herbal Pharmacology Compilation Committee): Korean Medical Pharmacology. 3rd edition. Shinnil Books, Seoul, pp507-511, 2010 (In Korean).

13. Ju DH, Liu MJ, Zhao HY and Wang J: Mechanisms of 'kidney governing bones' theory in traditional Chinese medicine. Front Med 8: 389-393, 2014.

14. Oliveira AS, Cercato LM, de Santana Souza MT, Melo AJO, Lima BDS, Duarte MC, Araujo AAS, de Oliveira E Silva AM and Camargo EA: The ethanol extract of Leonurus sibiricus L. induces antioxidant, antinociceptive and topical anti-inflammatory effects. J Ethnopharmacol 206: 144-151, 2017.

15. Sitarek P, Rijo P, Garcia C, Skała E, Kalemba D, Białas AJ, Szemraj J, Pytel D, Toma M, Wysokińska H and Sliwiński T: Antibacterial, anti-inflammatory, antioxidant, and antiproliferative properties of essential oils from hairy and normal roots of Leonurus sibiricus L. and their chemical composition. Oxid Med Cell Longev 2017: 7384061, 2017.

16. He YL, Shi JY, Peng C, Hu LJ, Liu J, Zhou QM, Guo L and Xiong L: Angiogenic effect of motherwort (Leonurus japonicus) alkaloids and toxicity of motherwort essential oil on zebrafish embryos. Fitoterapia 128: 36-42, 2018.

17. Ginaldi L, Di Benedetto MC and De Martinis M: Osteoporosis, inflammation and ageing. Immun Ageing 2: 14, 2005.

18. Kim JY, Cheon YH, Kwak SC, Baek JM, Yoon KH, Lee MS and Oh J: Emodin regulates bone remodeling by inhibiting osteoclastogenesis and stimulating osteoblast formation. $\mathrm{J}$ Bone Miner Res 29: 1541-1553, 2014.

19. Kim KJ, Yeon JT, Choi SW, Moon SH, Ryu BJ, Yu R, Park SJ, Kim SH and Son YJ: Decursin inhibits osteoclastogenesis by downregulating NFATc1 and blocking fusion of pre-osteoclasts. Bone 81: 208-216, 2015.

20. Tschop MH, Speakman JR, Arch JR, Auwerx J, Bruning JC, Chan L, Eckel RH, Farese RV Jr, Galgani JE, Hambly C, et al: A guide to analysis of mouse energy metabolism. Nat Methods 9: 57-63, 2011.

21. Mizutani H, Ishihara Y, Izawa A, Fujihara Y, Kobayashi S, Gotou H, Okabe E, Takeda H, Ozawa Y, Kamiya Y, et al: Lipopolysaccharide of Aggregatibacter actinomycetemcomitans up-regulates inflammatory cytokines, prostaglandin E2 synthesis and osteoclast formation in interleukin-1 receptor antagonist-deficient mice. J Periodontal Res 48: 748-756, 2013.

22. Nason R, Jung JY and Chole RA: Lipopolysaccharide-induced osteoclastogenesis from mononuclear precursors: A mechanism for osteolysis in chronic otitis. J Assoc Res Otolaryngol 10: 151-160, 2009.

23. Kim JH, Kim EY, Lee B, Min JH, Song DU, Lim JM, Eom JW, Yeom M, Jung HS and Sohn Y: The effects of Lycii Radicis Cortex on RANKL-induced osteoclast differentiation and activation in RAW 264.7 cells. Int J Mol Med 37: 649-658, 2016.

24. Yang L, Liu S, Mu S, Man X, Ba G, Guo R, Li Y, Zhou L, Yang $\mathrm{L}$ and $\mathrm{Fu} \mathrm{Q}$ : Leonurine hydrochloride promotes osteogenic differentiation and increases osteoblastic bone formation in ovariectomized mice by Wnt/ $\beta$-catenin pathway. Biochem Biophys Res Commun 504: 941-948, 2018. 
25. Wang D, Christensen K, Chawla K, Xiao G, Krebsbach PH and Franceschi RT: Isolation and characterization of MC3T3-E1 preosteoblast subclones with distinct in vitro and in vivo differentiation/mineralization potential. J Bone and Miner Res 14: 893-903, 1999.

26. Collin-Osdoby P and Osdoby P: RANKL-mediated osteoclast formation from murine RAW 264.7 cells. Methods Mol Biol 816: 187-202, 2012.

27. Bills CE, Eisenberg H and Pallante SL: Complexes of organic acids with calcium phosphate: The von Kossa stain as a clue to the composition of bone mineral. Johns Hopkins Med J 128 : 194-207, 1971.

28. Gregory CA, Gunn WG, Peister A and Prockop DJ: An Alizarin red-based assay of mineralization by adherent cells in culture: Comparison with cetylpyridinium chloride extraction. Anal Biochem 329: 77-84, 2004

29. Ogasawara T, Kawaguchi H, Jinno S, Hoshi K, Itaka K, Takato T, Nakamura K and Okayama H: Bone morphogenetic protein 2-induced osteoblast differentiation requires Smad-mediated down-regulation of Cdk6. Mol Cell Biol 24: 6560-6568, 2004

30. Jao HY, Hsu JD, Lee YR, Lo CS and Lee HJ: Mulberry water extract regulates the osteoblast/osteoclast balance in an ovariectomic rat model. Food Funct 7: 4753-4763, 2016

31. Shim KS, Lee CJ, Yim NH, Gu MJ and Ma JY: Alpinia officinarum stimulates osteoblast mineralization and inhibits osteoclast differentiation. Am J Chin Med 44: 1255-1271, 2016.

32. Golub EE, Harrison G, Taylor AG, Camper S and Shapiro IM: The role of alkaline phosphatase in cartilage mineralization. Bone Miner 17: 273-278, 1992.

33. Gordon JA, Tye CE, Sampaio AV, Underhill TM, Hunter GK and Goldberg HA: Bone sialoprotein expression enhances osteoblast differentiation and matrix mineralization in vitro. Bone 41: 462-473, 2007.

34. Morinobu M, Ishijima M, Rittling SR, Tsuji K, Yamamoto $H$ Nifuji A, Denhardt DT and Noda M: Osteopontin expression in osteoblasts and osteocytes during bone formation under mechanical stress in the calvarial suture in vivo. J Bone Miner Res 18: 1706-1715, 2003

35. Huang W,Carlsen B, Rudkin G, Berry M, Ishida K, Yamaguchi DT and Miller TA: Osteopontin is a negative regulator of proliferation and differentiation in MC3T3-E1 pre-osteoblastic cells Bone 34: 799-808, 2004.

36. Rosset EM and Bradshaw AD: SPARC/osteonectin in mineralized tissue. Matrix Biol 52-54: 78-87, 2016

37. Delany AM, Kalajzic I, Bradshaw AD, Sage EH and Canalis E: Osteonectin-null mutation compromises osteoblast formation, maturation, and survival. Endocrinology 144: 2588-2596, 2003.

38. Hurley MM, Abreu C, Harrison JR, Lichtler AC, Raisz LG and Kream BE: Basic fibroblast growth factor inhibits type I collagen gene expression in osteoblastic MC3T3-E1 cells. J Biol Chem 268: 5588-5593, 1993.

39. Hayman AR: Tartrate-resistant acid phosphatase (TRAP) and the osteoclast/immune cell dichotomy. Autoimmunity 41: 218-223, 2008.

40. Sheu TJ, Schwarz EM, Martinez DA, O'Keefe RJ, Rosier RN, Zuscik MJ and Puzas JE: A phage display technique identifies a novel regulator of cell differentiation. J Biol Chem 278: 438-443, 2003.

41. Marchisio PC, Cirillo D, Naldini L, Primavera MV, Teti A and Zambonin-Zallone A: Cell-substratum interaction of cultured avian osteoclasts is mediated by specific adhesion structures. J Cell Biol 99: 1696-1705, 1984.

42. Iotsova V, Caamano J, Loy J, Yang Y, Lewin A and Bravo R: Osteopetrosis in mice lacking NF-kappaB1 and NF-kappaB2. Nat Med 3: 1285-1289, 1997.

43. Miyazaki T, Katagiri H, Kanegae Y, Takayanagi H, Sawada Y, Yamamoto A, Pando MP, Asano T, Verma IM, Oda H, et al: Reciprocal role of ERK and NF-kappaB pathways in survival and activation of osteoclasts. J Cell Biol 148: 333-342, 2000.

44. David JP, Sabapathy K, Hoffmann O, Idarraga MH and Wagner EF: JNK1 modulates osteoclastogenesis through both c-Jun phosphorylation-dependent and -independent mechanisms. J Cell Sci 115: 4317-4325, 2002.

45. Matsumoto M, Kogawa M, Wada S, Takayanagi H, Tsujimoto M, Katayama S, Hisatake K and Nogi Y: Essential role of p38 mitogen-activated protein kinase in cathepsin $\mathrm{K}$ gene expression during osteoclastogenesis through association of NFATc1 and PU.1. J Biol Chem 279: 45969-45979, 2004.
46. Matsumoto M, Sudo T, Saito T, Osada $H$ and Tsujimoto $M$ Involvement of p38 mitogen-activated protein kinase signaling pathway in osteoclastogenesis mediated by receptor activator of NF-kappa B ligand (RANKL). J Biol Chem 275: 31155-31161, 2000.

47. Grigoriadis AE, Wang ZQ, Cecchini MG, Hofstetter W, Felix R, Fleisch HA and Wagner EF: c-Fos: A key regulator of osteoclast-macrophage lineage determination and bone remodeling. Science 266: 443-448, 1994.

48. Takayanagi H, Kim S, Koga T, Nishina H, Isshiki M, Yoshida H, Saiura A, Isobe M, Yokochi T, Inoue J, et al: Induction and activation of the transcription factor NFATc1 (NFAT2) integrate RANKL signaling in terminal differentiation of osteoclasts. Dev Cell 3: 889-901, 2002.

49. Sundaram K, Nishimura R, Senn J, Youssef RF, London SD and Reddy SV: RANK ligand signaling modulates the matrix metalloproteinase-9 gene expression during osteoclast differentiation. Exp Cell Res 313: 168-178, 2007.

50. Troen BR: The role of cathepsin $\mathrm{K}$ in normal bone resorption. Drug News Perspect 17: 19-28, 2004.

51. Miyazaki T, Tanaka S, Sanjay A and Baron R: The role of c-Src kinase in the regulation of osteoclast function. Mod Rheumatol 16: 68-74, 2006.

52. Battaglino R, Kim D, Fu J, Vaage B, Fu XY and Stashenko P: $\mathrm{C}$-myc is required for osteoclast differentiation. J Bone and Miner Res 17: 763-773, 2002.

53. Sharma SM, Bronisz A, Hu R, Patel K, Mansky KC, Sif S and Ostrowski MC: MITF and PU.1 recruit p38 MAPK and NFATc1 to target genes during osteoclast differentiation. J Biol Chem 282 15921-15929, 2007.

54. Kim JH, Kim K, Jin HM, Youn BU, Song I, Choi HS and Kim N: Upstream stimulatory factors regulate OSCAR gene expression in RANKL-mediated osteoclast differentiation. J Mol Biol 383 502-511, 2008

55. Choi BY, Park CH, Na YH, Bai HW, Cho JY and Chung BY: Inhibition of RANKL-induced osteoclast differentiation through the downregulation of c-Fos and NFATc1 by Eremochloa ophiuroides (centipedegrass) extract. Mol Med Rep 13: 4014-4022, 2016.

56. Han SY and Kim YK: Berberine suppresses RANKL-induced osteoclast differentiation by inhibiting c-fos and NFATc1 expression. Am J Chin Med 47: 439-455, 2019.

57. Lee SH, Rho J, Jeong D, Sul JY, Kim T, Kim N, Kang JS, Miyamoto T, Suda T, Lee SK, et al: v-ATPase V0 subunit d2-deficient mice exhibit impaired osteoclast fusion and increased bone formation. Nat Med 12: 1403-1409, 2006.

58. Yang M, Birnbaum MJ, MacKay CA, Mason-Savas A, Thompson B and Odgren PR: Osteoclast stimulatory transmembrane protein (OC-STAMP), a novel protein induced by RANKL that promotes osteoclast differentiation. J Cell Physiol 215: 497-505, 2008

59. Miyaura C, Inada M, Matsumoto C, Ohshiba T, Uozumi N, Shimizu T and Ito A: An essential role of cytosolic phospholipase A2alpha in prostaglandin E2-mediated bone resorption associated with inflammation. J Exp Med 197: 1303-1310, 2003.

60. Welshons WV, Wolf MF, Murphy CS and Jordan VC: Estrogenic activity of phenol red. Mol Cell Endocrinol 57: 169-178, 1988.

61. Khosla S, Oursler MJ and Monroe DG: Estrogen and the skeleton. Trends Endocrinol Metab 23: 576-581, 2012.

62. Geller SE and Studee L: Contemporary alternatives to plant estrogens for menopause. Maturitas 55 (Suppl 1): S3-S13, 2006.

63. Tao J, Zhang P, Liu G, Yan H, Bu X, Ma Z, Wang N, Wang G and Jia W: Cytotoxicity of Chinese motherwort (YiMuCao) aqueous ethanol extract is non-apoptotic and estrogen receptor independent on human breast cancer cells. J Ethnopharmacol 122 234-239, 2009.

This work is licensed under a Creative Commons Attribution-NonCommercial-NoDerivatives 4.0 International (CC BY-NC-ND 4.0) License. 